\title{
China OBOR in Perspective of High-speed Railway (HSR) -Research on OBOR Economic Expansion Strategy of China
}

\author{
Chen Lanjian ${ }^{1, *}$, Zhang Wei ${ }^{2}$ \\ ${ }^{1}$ School of Business and Tourism, Yunnan University, China \\ ${ }^{2}$ Department of Financial Management \& EDP Training Center, Yunnan University, China
}

Copyright $(\mathcal{C} 2015$ by authors, all rights reserved. Authors agree that this article remains permanently open access under the terms of the Creative Commons Attribution License 4.0 International License

\begin{abstract}
This paper aims to depict the economic expansion strategy [1] deployments for OBOR home and abroad as completely and digitally as possible in the following 3 aspects: inner/outer regions, financing sector and China HSR; further makes analyses and explanations on the above 3 strategic layouts, e.g., Xinjiang and Fujian main hubs, HSR relations between AIIB and OBOR, China HSR cooperation with the countries and regions along the ways of OBOR in where China views HSR as the key to acquiring and exploiting varied resources such as energy, mineral resources, high-tech, financing, infrastructure and agriculture, etc., HSR falls within one of the core benefits of China; visualizes a close loop framework of OBOR,
\end{abstract}

overcapacity production industries, HSR line construction status quo as well as the near future development sketch map, etc. via figures and tables; and furnishes the OBOR economic expansion strategy with 5 valuable suggestions finally. The aim of OBOR is to transfer the domestic excess capacity, excess foreign exchange reserves and excess manpower with the following competitive advantages, e.g., capacity, cost, differentiation and resources acquirement/ exploration to the outside world.

Keywords OBOR (One Belt One Road), Economic Expansion Strategy, High-speed Railway (HSR)

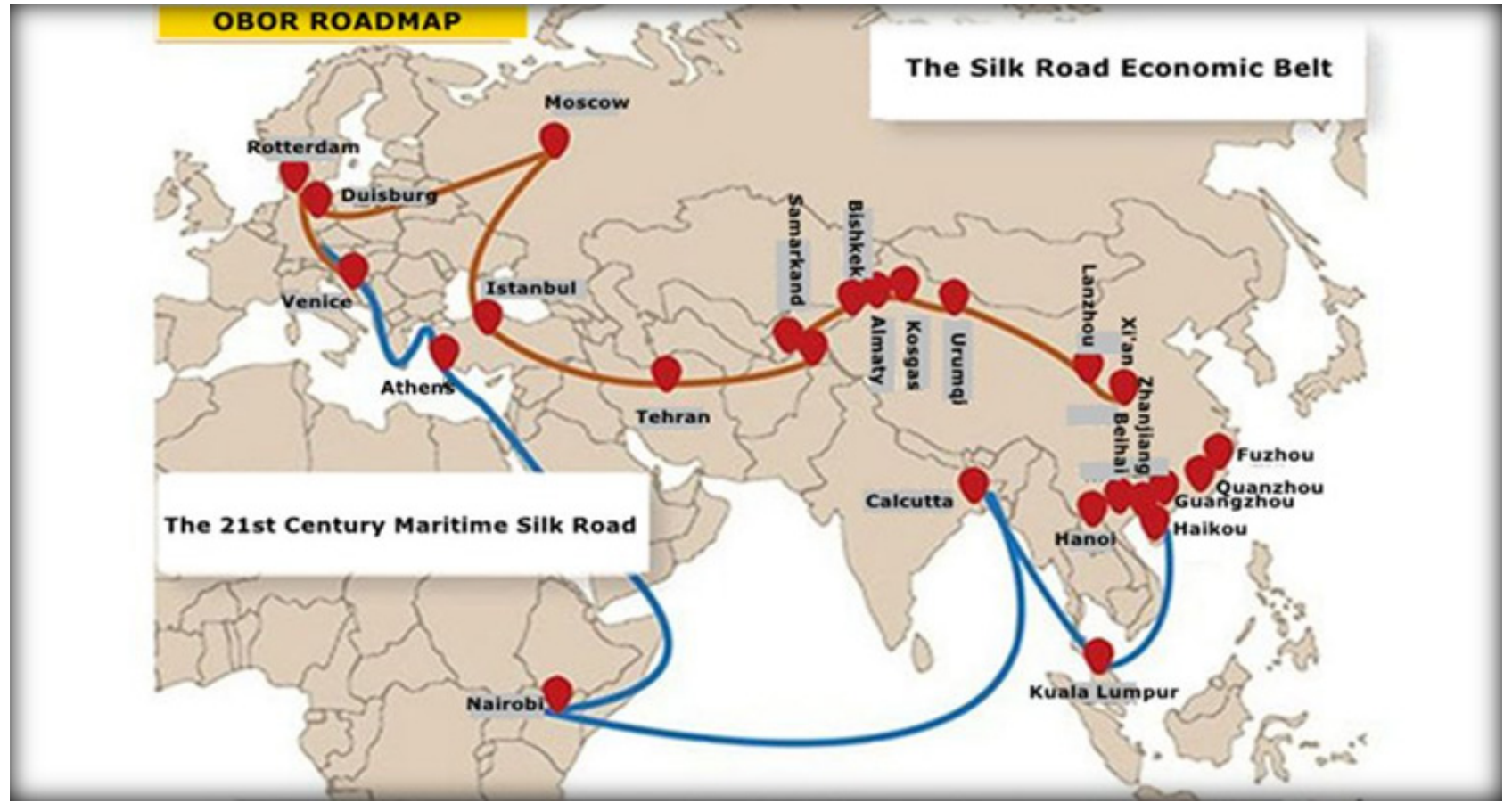

Source: http://www.tkpwest.com/show/F1/S1/T1/20141129/3244.htm

Figure 1. The close loop of SREB \& $21^{\mathrm{ST}} \mathrm{CMSR}$ 


\section{Brief Introduction}

China started the 'Silk Road Economic Belt and 21st Century Maritime Silk Road' (One Belt and One Road, OBOR) economic expansion strategy in 2013. Now China steps on Arthur Thompson growth strategy route, identifies and makes use of its advantageous areas in capacity, capital, technology, cost, manpower, etc. in order to digest excess capacity production as well as find the potential market home and abroad, in particular, the high-speed railway (HSR) infrastructure market. The goal of this paper attempts to show the OBOR strategy from the angle of all-round deployments in geography, financing and high-speed railway (HSR).

\section{Economic Expansion Strategy for OBOR}

\subsection{Definition of OBOR}

The OBOR strategy encompasses a kind of economic expansion strategy that China pursues. China has become the world's $2^{\text {nd }}$ largest economic entity with over \$10-trillion-dollar GDP [2] and the world's largest trading entity with imports and exports of \$ 4.16 trillion US dollars. [3] The rise of China must undergo the economic expansion strategy for long-term or short-term periods, because only if the growth strategy, by nature, enables China to constantly expand Chinese economies of scale, can China turn out to be a big country from a less competitive one.

China first widely pushes its own OBOR economic expansion strategy that is composed of the Silk Road Economic Belt (SREB) and $21^{\text {st }}$ Century Maritime Silk Road $\left(21^{\text {ST }}\right.$ CMSR) sub-strategies, namely:

$$
\mathrm{OBOR}=\mathrm{SREB}+21^{\mathrm{ST}} \mathrm{CMSR} \text {, }
$$

Hereinafter referred to as the OBOR economic expansion strategy in this article. Among them, the Silk Road Economic Belt ( SREB ) strategy is to cover the areas from the Southeast Asia, Central Asia and Middle East countries which they assimilate finally together as a regional economic entity to lead to Europe, forming a trend of Eurasian Economic Integration. Whereas, the $21^{\text {st }}$ Century Maritime Silk Road ( $21^{\text {ST }}$ CMSR) strategy is to connect China with Asia, Africa and Europe continents in where OBOR can eventually form a closed loop on both land and sea routes that serve as the trading channels and economic corridors. [4]

The SREB refers to the Silk Road Economic Belt. In September of 2013, China President Xi Jinping proposed to jointly construct the Silk Road Economic Belt (SREB) at Nazarbayev University, Kazakhstan, it is a new regional economic development idea derived from the concept of the ancient Silk Road which was ever a land passage on where Envoy Zhang Qian (the Western Han Dynasty, 202 BC to AD 9, viz. 2,217 years ago) went on mission to the western regions from Changan (now Shanxi Xi'an) as starting point, to the Guanzhong Plain, Hexi Corridor, Tarim Basin and
Central Asian areas such as Transoxiana and Greater Iran between the Syr Darya River and Oxus River, and finally reached the Mediterranean countries.

The $21^{\text {st }}$ CMSR involves the $21^{\text {st }}$ Century Maritime Silk Road. In October of 2013, While China President Xi Jinping paid a visit to the ASEAN countries and proposed this program. Ever since the Qin and Han Dynasty (221 BC to AD 221, viz. 2,236 years ago) opened the China ancient Maritime Silk Road on where it has always been an important bridge between the East and West economic and cultural exchanges, and since ancient times, in particular, the Southeast Asian regions have always played an important hub role on SREB. The $21^{\text {st }}$ CMSR strategic partners include not only ASEAN, point leading line, line leading plane, but also enhance exchanges in the countries and regions along the lines of OBOR, it will communicate with ASEAN, South Asia, West Asia, North Africa, Europe and other major economic market chains so as to work out the expansion strategy facing the South China sea, Pacific and India Oceans strategically cooperated economic belt as well as to develop a long-term goal of integrating economy and trade into Asia, Europe and Africa.

Table 1. the world's $2^{\text {nd }}$ economic entity $\& 1^{\text {st }}$ trading entity.

\begin{tabular}{|c|c|}
\hline \multicolumn{2}{|c|}{ Physical Volume of the OBOR } \\
\hline Coverage of demography & 4.4 billion \\
\hline $\begin{array}{c}\text { Scale of Economies } \\
\text { Goods \& services exports in the } \\
\text { whole world }\end{array}$ & 21 trillion US dollars \\
\hline $\begin{array}{c}\text { Countries \& regions along the } \\
\text { OBOR }\end{array}$ & $\begin{array}{c}27.9 \% \\
\text { (maybe including 65 ones } \\
\text { globally) }\end{array}$ \\
\hline $\begin{array}{l}\text { Source: Shen Zewei, Official Media: } \\
07 / 11 / 2014\end{array}$ \\
\hline
\end{tabular}

Preliminarily estimating, there would be 27 countries (maybe involved in 65 ones around the world) along the ways of OBOR with the total population of about 4.4 billion, accounting for $63 \%$ of the world's population; the total economy about $\$ 21$ trillion US dollars, taking up about $29 \%$ of the total global economy.

\subsection{Arthur Thompson Theoretical Framework of Economic Expansion Strategy}

According to Arthur Thompson's strategic concepts, he argues that to acquire the competitive advantages is to take advantage of economic expansion strategy successfully, making it relies on the following strategic actions: cost, differentiation or resources/capacity-oriented ones; any successful action can be divided into 3 phases, viz., the first phase Inception, second phase Benefit and third phase Loss; there are 6 types of successful actions as follows:

- To take steps to catch up with or surpass the rivalry strengths;

- To adopt measures to make use of the rivalry weaknesses;

- To attack the fronts from a multi-access;

- To conduct summative actions;

- To engage in guerrilla actions;

- To pursue preemption actions. 


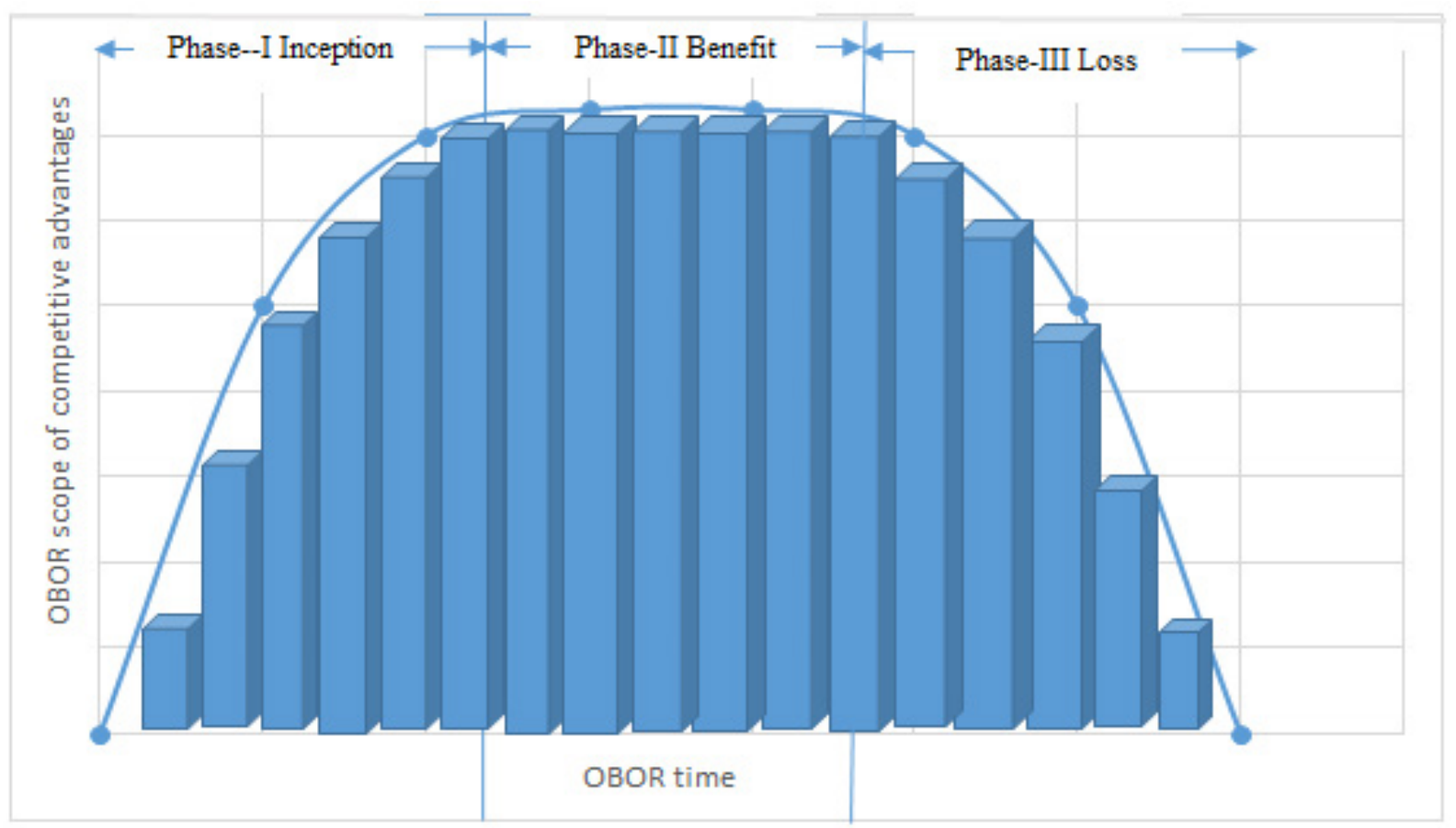

Figure 2. OBOR continuum from inception to loss

The First Phase-Inception in which China initiates the OBOR economic expansion strategy successfully (e.g., AIIB establishment, that is, the Asia Infrastructure Investment Bank, a regional multilateral bank created and proposed by China in October of 2014);

The Second Phase-Benefit in which China shall benefit from the scope of competitive advantages in infrastructure, energy resources, capacity, foreign exchange reserves, manpower, and so on.

The Third Phase-Loss in which the rivalry shall gobble up the OBOR competitive advantages through simulation, copy or attack.

Based on Arthur Thompson's theory, China utilizes an economic expansion strategy to obtain the globally competitive advantages via a creative OBOR economic expansion strategy that is hard to be defeated by the competitors. OBOR adopts the multi-way to win the global market, for instance, the multi-channel access to oil/gas resources. OBOR takes actions to catch up with and challenge competitors. At the same time, China can not only provide equal or even better products, but also compete at the low prices, e.g., to help the countries along the ways of OBOR with building high-speed railway, highway, digging the canal, and also to provide them with infrastructure construction investment. The aim of OBOR is to transfer the domestic excess capacity, excess foreign exchange reserves and excess manpower in the following competitive advantages such as capacity, cost, differentiation and resources acquirement/ exploration to the outside world.

\subsection{The East Meeting the West in OBOR Economic Growth Strategy}

\subsubsection{Tai Ji (The Great Ultimate) Element}

Chinese believe in Tai Ji, an ancient philosophy in China, which argues that "Yin and Yang are the Tao", Tao consists of the heaven Tao, earth Tao and man Tao, which says that all things have two aspects of Yin and Yang, for example, heaven and earth, day and night, mountains and rivers, man and woman, rigid and flexible, etc. and both sides change constantly, possess some ties relevantly between them. Of which the man Tao mainly refers to thought, thought decides behavior and attitude. Tai Ji advocates that people should respect their own ideas, respect the laws of nature and learn to control their emotions.

Thus, Chinese like fuzzy, softness, China does not pursue the American boxing to KO (knockout) anybody, the American boxing focuses on strength style, straightness, strikeout, and so on, the best shot is to KO (knockout) opponents, then everything is clear-cut; but China tries to resolve all the movements of opponents. Therefore, Chinese like Tai Ji boxing, too, and in fact, Tai Ji boxing is indeed cleverer than American boxing. OBOR applies well Tai Ji idea to the present situation and believes Rome was not built in a day. If China thought that the situation is in favor, then China would have won right away, it is out of the question, because OBOR is a process of integrating hearts and minds of the peoples along the countries of OBOR, to integrate peoples is much slower than to build high-speed railway and highway, lay oil/gas pipelines or erect power stations, etc. Only China reins the hearts and minds of peoples, can OBOR move in a right orientation.

\subsubsection{Feelings of the World}

The OBOR strategic thinking contains the feelings of the world 'All serves me, I serve all, too' rather than definitely 
taking a country's selfish interests into considerations. After the 30-year-reform, opening up and rapid development, China's economy has become an indispensable link in the global resources and capital markets. Initiating OBOR is not only to more effectively integrate global resources and capital, but also to more effectively give full play in industry and capital advantages so that the countries along the ways of OBOR can achieve common development and prosperity.

Mr. Zbigniew Brzezinski, a famous American geopolitical strategist, restated that Thucydides Trap and said, "China and the United States is about to fall into the trap of Thucydides. This phenomenon derives from the ancient Greek and Roman, since then people began to talk about that all emerging countries finally would inevitably fall into a trap of challenging the old imperial. China provides the countries along the OBOR with money, technology, equipment, etc. to engage in infrastructure construction such as high-speed railway, highway, oil and gas pipelines, power stations, etc.), which enable peoples of the countries along the OBOR to enjoy the convenience and progress of public infrastructure, it can either solve China's excess capacity, foreign exchange reserves and labor or pull the domestic demand of the countries along the OBOR, and also avoid the zero sum game, achieve mutual benefits and smart win-win situations between China and the countries along the OBOR. This means that not all of the rise of great powers must fall into the trap of Thucydides; the zero sum game is no longer necessarily a unique choice among great powers.

Therefore, OBOR is not only beneficial to China, but also conducive to China's strategic choice. OBOR consists of both Arthur Thompson growth strategy and the thinking elements of oriental management; OBOR is a typical combination of the east and west thinking.

\subsection{Domestic Context of OBOR}

On the basis of Arthur Thompson theory, China overcapacity production means a sort of advantage; in the meantime, its transfer brooks no delay!

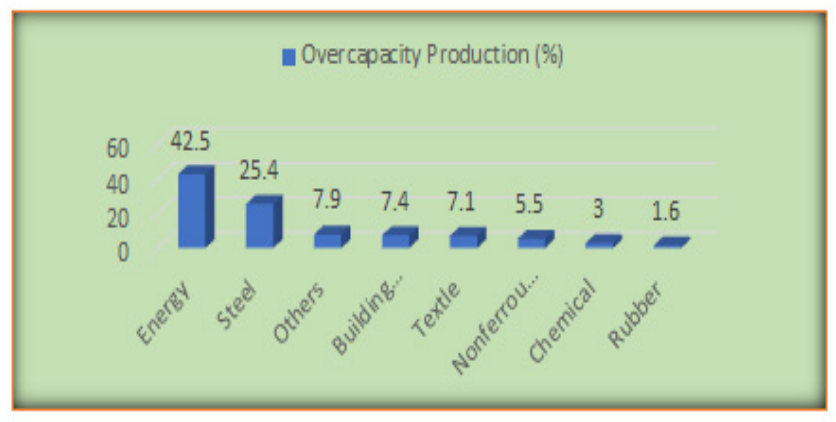

Source: http://xianhuo.hexun.com/2014-01-15/161451500.html

Figure 3. China overcapacity percentage distribution

OBOR serves as an important, long-term national development economic expansion strategy which is to solve several strategic problems such as China excess capacity market, resources acquisition, strategic depth, strengthening trade development, national security and trade dominance, etc. China excess capacity causes plenty of problems on economic operations, through the OBOR, it is a very good means to open up new export market. China has both excess capacity and excess foreign exchange assets; whereas, the emerging markets and less developed countries still lack the construction of infrastructure, China makes full use of foreign exchange reserves as driving global growth capital, at the same time, the China capital output drives excess capacity to be digested abroad.

\section{China All-round Domestic and Overseas Deployment for OBOR Economic Expansion Strategy}

Within the OBOR, China has domestic 23 provinces, municipalities directly under central government and autonomous regions that have started a comprehensive OBOR deployment: the Silk Road Economic Belt (SREB) contains 6 provinces and autonomous regions in N.W. China, 5 provinces and autonomous regions in S. W. China; the $21^{\text {st }}$ Century Maritime Silk Road ( $21^{\text {ST }}$ CMSR ) includes 8 coastal provinces and municipalities in S. E. China; together with other 4 provinces involved in OBOR construction.

\subsection{Deployment for OBOR at Home}

The deployment for SREB: 6 Provinces and Autonomous Regions in Northwest China, including Xinjiang autonomous region, Qinghai province, Gansu province, Shaanxi province, Ningxia autonomous region, Inner Mongolia Autonomous Region; 1Municipality, 4 Provinces and Autonomous Regions in Southwest China involve Chongqing municipality, Sichuan province, Yunnan province, Tibet and Guangxi autonomous regions.

The deployment for $21^{\text {st }}$ CMSR: 8 Coastal Municipalities and Provinces in Southeast China encompass Shanghai municipality, Tianjin municipality, Jiangsu province, Zhejiang province, Fujian province, Guangdong province, Hainan province and Shandong province.

The deployment for Integrating 4 Provinces and Autonomous Regions into SREB and $21^{\text {st }}$ CMSR: 4 Provinces and autonomous regions integrated locations pertain to Heilongiiang province, Henan province, Hubei province and Liaoning province.

\subsection{Deployment for OBOR Abroad}

The Silk Road Economic Belt ( SREB) strategy is to cover the areas from the Southeast Asia, Central Asia and Middle East countries which they assimilate finally together as a regional economic entity to lead to Europe, forming a trend of Eurasian Economic Integration. Whereas, the $21^{\text {st }}$ Century Maritime Silk Road ( $21^{\mathrm{ST}}$ CMSR) strategy is to connect China with Asia, Africa and Europe continents in where OBOR can eventually form a closed loop on both land and 
sea routes that serve as the trading channels and economic corridors. [5]

\section{Analyses and Explanations of Deployment for OBOR Economic Expansion Strategy}

23 provinces, municipalities and autonomous regions engage in an overall layout for the OBOR economic expansion strategy, of which Xinjiang and Fujian become the main hubs, there are the reasons analyzed as follows:

\subsection{The Xinjiang Main Hub}

It is Pakistan's Gwadar port from where China imports oil at the shortest distance in India Ocean. This port is situated near the Persian Gulf, if China loaded and unloaded oil and gas with the pipelines to transport to Xinjiang, it might save tens of thousands of kilometers of the voyage. Thus, China's oil route can simply bypass 12,000 km of the Malacca Strait, directly from the Gwadar port on board through a high-speed railway (HSR) or pipelines there will cover only about 2,400 $\mathrm{km}$ into Kashgar in Xinjiang. [6] Besides, China and Pakistan have reached an agreement on a pipeline from Gwadar port to Iran, which means that China's oil and gas will be fully delivered through the pipelines rather than tankers from the Middle East. If Gwadar Port has been put into use, the next step for the Sino-Pakistan economic corridor shall be to conduct the large-scale construction projects such as high-speed rail, oil transmission pipeline, highways, electric power, communications, etc.

Xinjiang can be one of core areas in OBOR, the energy industry has determined its path of development in Xinjiang, namely: Three Bases and One Passageway. Three bases refer to a large oil/gas production, processing and reserve base; a large-scale coal, coal power and coal chemical base and a large-scale wind power base; One Passageway encompasses one national energy resources passageway on land.

There is an area of 1.66 million $\mathrm{km}^{2}$ in Xinjiang, accounting for about $1 / 6$ of China, except for the ocean diversity of surface topography, Xinjiang boasts its richer underground resources, of which the coal reserves reach $37.7 \%$ of the total China; the oil/gas reserves contain 30 billion tons, taking up more than $25 \%$ of the total China [7]. In addition, the wind/solar energy is the most promising clean energy in Xinjiang, and also available in the forefront of China.

As such, Xinjiang is China's coal, oil, natural gas important strategic substitution areas and one key energy passageway as well.

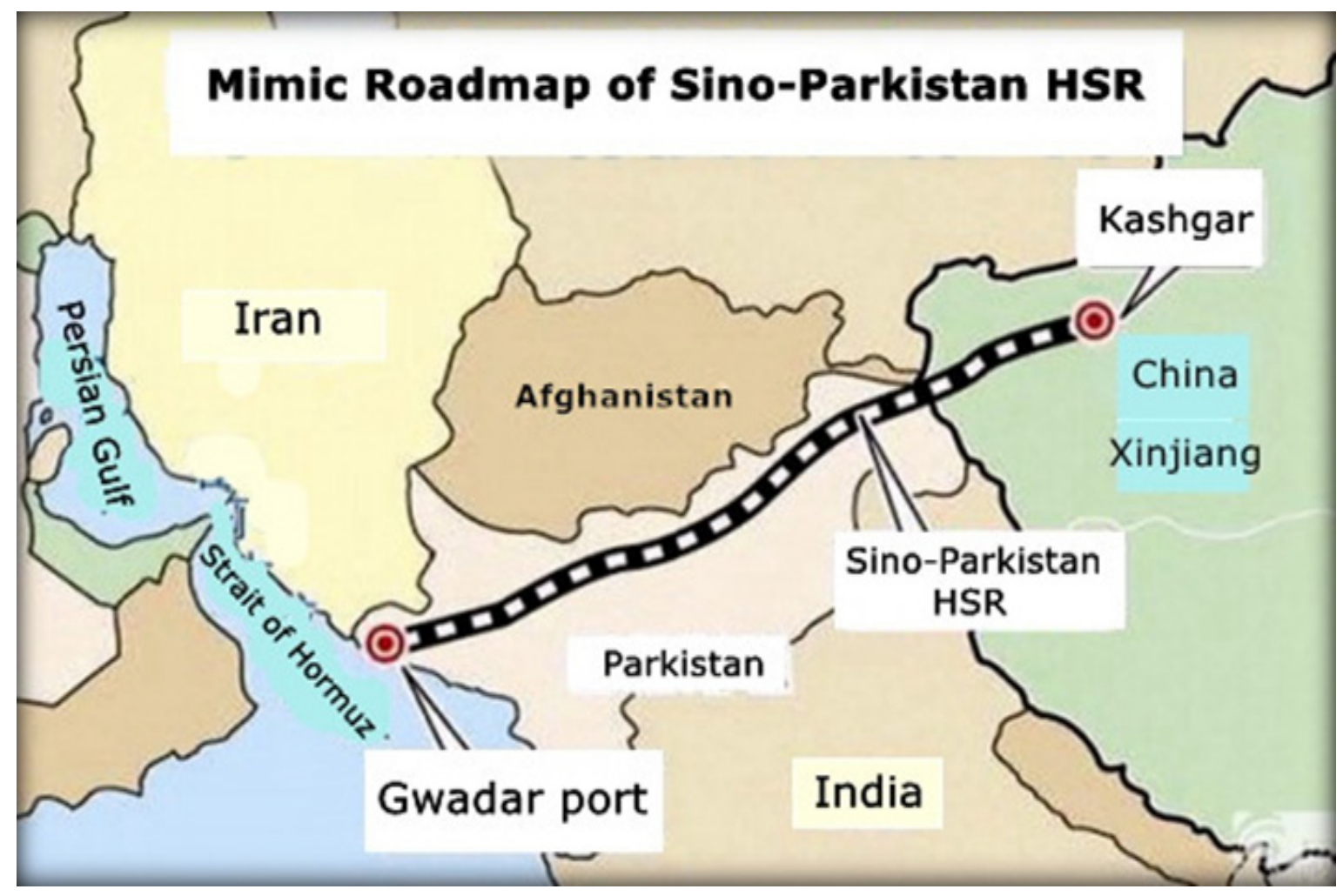

Source: http://www.360doc.com/content/15/0428/22/9874889_466675389.shtml

Figure 4. Mimic Roadmap of Sino-Pakistan HSR 


\subsection{The Fujian Main Hub}

According to Mr. Lin Jialai, a CPPCC (Chinese People's Political Consultative Conference) member, put forth a proposal at the 2015 National Congress of the CPPCC: Establishing a set of goals of achieving an economic integration to promote the Haixi economic development and resonance between both sides of the Taiwan Straits. And also, he submitted 5 proposals to the 2015 CPPCC session, one of them was recommended to promote the economic integration between Fujian and Taiwan, promote the Haixi economic development first through the construction of a Xiamen-Kinmen bridge across the sea. His 5 proposals include also the following tens of recommendations: Fujian and Taiwan residents traveling to and fro border free; Fujian and Taiwan import and export goods mutual exemption of tariffs; Fujian and Taiwan double-sided vehicle license plate customs clearance free; to construct the Xiamen-Kinmen bridge; to allow Xiamen to declare the Taiwan city group construction; to build the subsea tunnel from the Pingtan Island straight through Taiwan $\mathrm{Hsinchu}$; to establish the cross-strait Buddhism and Buddhist art cultural base; to erect a sister city relationship between Taipei and Fuzhou, Kaohsiung and Xiamen; to allow the Fujian and Taiwan universities and vocational institutes to enroll students mutually; to strengthen medical cooperation between Fujian and Taiwan and allow patients to freely choose medical services; to specially approve Xiamen to set up the Xiamen Stock Exchange and to found the emergency relief organization between Fujian and Taiwan, etc. in a bit to urge the economic and cultural exchanges between Fujian and Taiwan. The Haixi Economic Zone refers to the west coast of Taiwan Straits, Fujian Province as the main body around its neighboring areas, its north and south parts connect both the Pearl and Yangtze River Delta Economic Zones, the east part links Taiwan Island, the west part links up Jiangxi vast hinterland. Generally speaking, Fujian characterizes in the world-class regional economic complex conducive to the return of Taiwan to the mainland.

\section{Deployment for Financing Source of OBOR Economic Expansion Strategy}

According to Arthur Thompson theory, China takes advantage of its capital via erecting financial institutions as follows:

AIIB refers to the Asia Infrastructure Investment Bank, a regional multilateral bank created and proposed by China in October of 2014, the main business is to aid in the construction of infrastructure of countries amidst Asia-Pacific regions, it will be headquarters-based in Beijing with legal fund $\$ 100$ billion US dollars, preliminary funds paid in $\$ 50$ million US dollars by China, accounting for $50 \%$. Apart from China, there have been altogether 57 countries to be willing to join AIIB as of April $15^{\text {th }}, 2015$, including Bangladesh, Brunei, Kampuchea, India, Indonesia, China, Jordan, Kazakhstan, Kuwait, Laos, Malaysia, Maldives,
Mongolia, China Burma, Nepal, Pakistan, Philippines, Oman, Qatar, Saudi Arabia, Singapore, South Korea, Sri Lanka, Tajikistan, Thailand, Turkey, Uzbekistan, Vietnam, Kyrgyzstan, Israel, Georgia the United Arab Emirates, Azerbaijan, Iran, Austria, Denmark, France, Germany, Italy, Spain, Holland, Luxemburg, Switzerland, Britain, Sweden, Finland, Norway, Iceland, Portugal, Poland, Russia, Malta, Australia, New Zealand, Brazil, Egypt and South Africa as its intended founding members, of which there are 30 founding ones already.[8]

There have been another 3 financial institutions such as The Silk Road Fund (SRF), founded in November of 2014 with $\$ 40$ billion US dollars, China takes up $100 \%$; The BRICs Development Bank (BRICDB), founded in July of 2014 with $\$ 100$ billion US dollars, China accounts for $41 \%$; [9] The SCO National Development Bank (SCONDB), founded in April of 1996 with the loan of over $\$ 50$ billion US dollars, China occupies $100 \%$.

China set up 3 financial institutions (AIIB, SRF and BRICDB) in series in 2014, and accounted for $63 \%$ of the total legal fund. Of course, China has been playing a leading role in OBOR economic expansion strategy.

Table 2. Financing Source for OBOR Economic Expansion Strategy

\begin{tabular}{|c|c|c|c|c|}
\hline \multicolumn{5}{|c|}{ Financing Source of OBOR } \\
\hline & SRF & AIIB & BRICDB & SCONDB \\
\hline Foundation Time & $\begin{array}{c}\text { Nov. of } \\
2014\end{array}$ & $\begin{array}{c}\text { Oct. of } \\
2014\end{array}$ & Jul. of 2014 & $\begin{array}{c}\text { Apr. of } \\
1996\end{array}$ \\
\hline $\begin{array}{c}\text { Member } \\
\text { Countries }\end{array}$ & 1 & 57 & 5 & 5 \\
\hline $\begin{array}{c}\text { Legal Fund } \\
\text { (US\$ billion) }\end{array}$ & 40 & 100 & 100 & $>50$ \\
\hline $\begin{array}{c}\text { Of which China } \\
\text { (US\$ billion) }\end{array}$ & 40 & 50 & 41 & 50 \\
\hline China \% & 100 & 50 & 41 & 100 \\
\hline
\end{tabular}

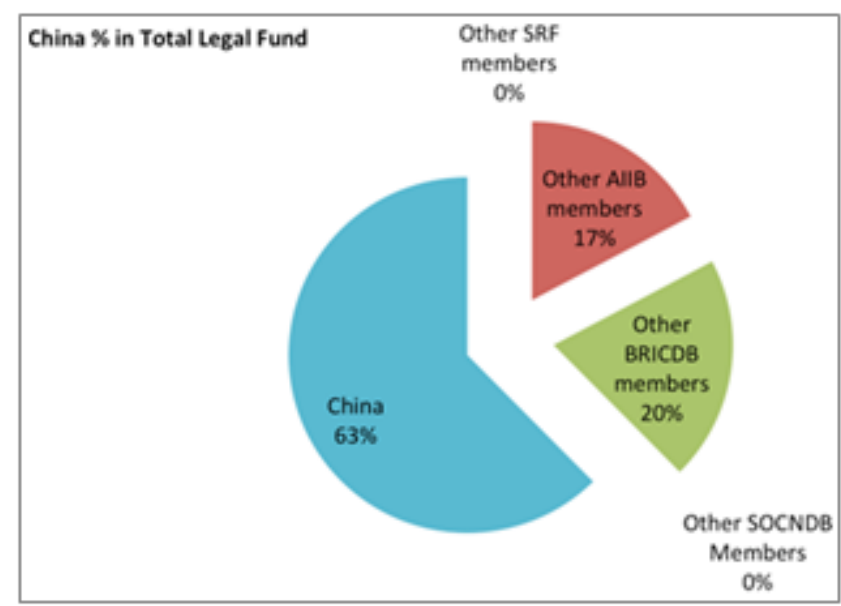

Figure 5. China $\%$ in total legal fund

AIIB, SRF, SCONDB and BRICDB aim at promoting the economic development and regional economic integration of Asian countries. Only if through the establishment of them and cooperation of the public, private sectors, can China effectively compensate for the gap of Asia infrastructure 
funding and drive the regional economic integration in Asia. They shall be conducive to expand global investment needs and support the world economic recovery; conducive to adopt the infrastructure projects to promote the economic growth, development of private economy and improve employment in Asia. They shall supply those high savings rate countries along the ways of OBOR with a platform for guiding their deposits to be invested directly in infrastructure construction, efficiently and effectively allocating capital, and ultimately promoting the rapid development of financial market in the Asian regions.

\section{China High-speed Railway, HSR}

Three are a number of cooperative domains in the OBOR economic expansion strategy. The countries along the lines of OBOR Asian economic system are able to engage in the cooperative development in the following fields: high-speed railway (HSR), nuclear power, military manufacturing, transportation, post and telecommunications, textile, food, pharmaceuticals, chemicals, agricultural products processing, production of consumer goods, machinery manufacturing and other industries in where to be invested, and the development of cooperation will also be carried out in agriculture, desert control, solar energy, environmental protection, etc.

According to Arthur Thompson theory, China takes the preemption action to give full play of its HSR capacity home and abroad, because China's high-speed railway operation mileage soared from $6,552 \mathrm{~km}$ in 2009 to $11,028 \mathrm{~km}$ in 2013 with an increase of $40.6 \%$ and an average annual rate of $10.2 \%$. Meanwhile, it is also the longest operating mileage all over the world.

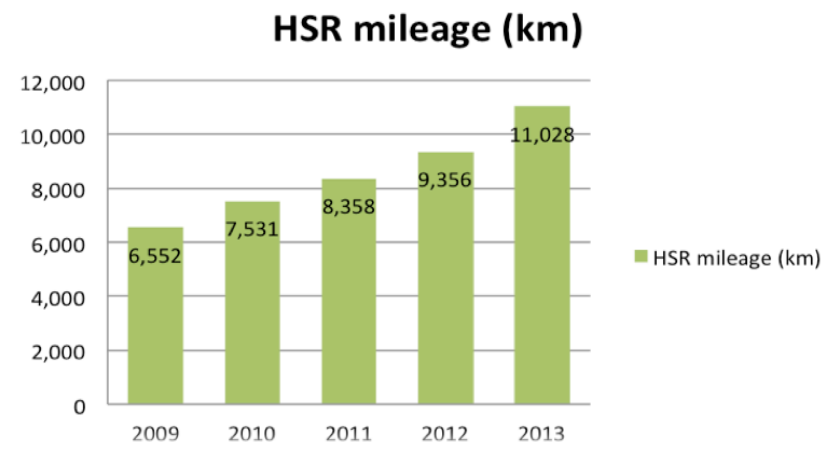

Source:

http://mp.weixin.qq.com/s? biz=MzA4MDczNDkwNg==\&mid=200634 $561 \& \mathrm{idx}=3 \& \mathrm{sn}=52 \mathrm{acaef} 81 \overline{06} 36 \mathrm{fe} 1 \mathrm{~d} 15 \mathrm{c} 74 \mathrm{~d} 2330 \mathrm{~b} 0198$

Figure 6. China HSR operating mileage (2009-2013)

\subsection{Domestic Deployment of HSR}

As stipulated in China railway provisions, the high-speed railway (HSR) refers to the design of running at more than $250 \mathrm{~km} / \mathrm{h}$ (including reserves), and the early operating at more than $200 \mathrm{~km} / \mathrm{h}$ passenger dedicated line (PDL). In 2004, China high-speed railway construction began from China railway and long-term program for HSR, of which the first real line was the Beijing-Tianjin Intercity HSR put into operation in August $1^{\text {st }}, 2008$ at $350 \mathrm{~km} / \mathrm{h}$. As of Dec. $28^{\text {th }}$, 2014, China HSR operated for a total mileage of over 16,000 $\mathrm{km}$, basically molded the "Four Vertical and Four Horizontal" trunks. China HSR operating mileage takes up about $50 \%$ of the world HRS mileage in which China is ranked $1^{\text {st }}$.

\subsection{Four Vertical and Horizontal Passenger Dedicated Lines (PDL) and HSRs}

The four vertical PDLs and HSRs consist of Jing (Beijing) -Hu (Shanghai) HSR, Beijing-Guangzhou-Shenzhen HSR, Jing (Beijing)-Ha HSR, Hang-Fu-Shen PDL (along the southeastern coasts of China); the four horizontal PDLs and HSRs compose Xu-Lan PDL (including Xu-Lian PDL), Hu (Shanghai)-Kun (Kunming) HSR, Qing-Tai PDL, Hu (Shanghai)-Han-Rong HSR. [10]

The "four vertical and four horizontal" unnecessarily arrive at up to the PDL and HSR level, a part of them is ranked as the $1^{\text {st }}$ class railroads, whereas the PDL level routes may not well be included within the "four vertical and four horizontal" network.

\subsubsection{The HSR Network of Four Vertical PDLs and HSRs}

\section{Jing-Hu (Beijing-Shanghai) HSR}

As of the end of 2012, the Jing-Hu (Beijing-Shanghai) HSR traffic situation as follows:

Through the following major train stations: Beijing South - Tianjin South - Ji'nan West - Xuzhou East - Bengbu South Nanjing South - Shanghai Hongqiao. A total length of about $1,318 \mathrm{~km}$, the design speed of $350 \mathrm{~km} / \mathrm{h}$, and a reserved space for up to $380 \mathrm{~km} / \mathrm{h}$. Jing-Hu (Beijing-Shanghai) HSR officially went into operations on June $30^{\text {th }}, 2011$, multiple units running at the highest speed of $300 \mathrm{~km} / \mathrm{h}$, the shortest running time between Beijing and Shanghai has been reduced to 4 hours 48 minutes. [11]

In addition, there is Bengbu - Hefei branch HSR line (namely He-Beng PDL) that is an important part of the Beijing-Fu PDL with a design speed of $350 \mathrm{~km} / \mathrm{h}$, passing through the Beijing, Tianjin, Shanghai and Hebei, Shandong, Anhui as well as Jiangsu four provinces, and connecting the Yangtze River Delta and Bohai Sea two economic zones. The He-Beng PDL opened across the board on Oct. $16^{\text {th }}$, 2012.

\section{Jing (Beijing)-Hong Kong PDL (Namely} Jing-Guang-Shen-Kong HSR)

Through the following major train stations: the Beijing West - Shijiazhuang - Zhengzhou - Wuhan - Changsha South - Guangzhou South-Shenzhen North-Hong Kong West kowloon. Beijing-Kong PDL encompasses Beijing-Shijiazhuang PDL, Shi-Wu PDL, and Wuhan-Guangzhou PDL, connecting the northern, central and southern regions of China with a design speed of $350 \mathrm{~km}$ $/ \mathrm{h}$, of which Beijing- Shenzhen section opened in Dec. $26^{\text {th }}$, 2012, Shenzhen-Kong is expected to open in 2016. 
Beijing-Harbin PDL

\section{Strategic Layout of China Mainland HSR}

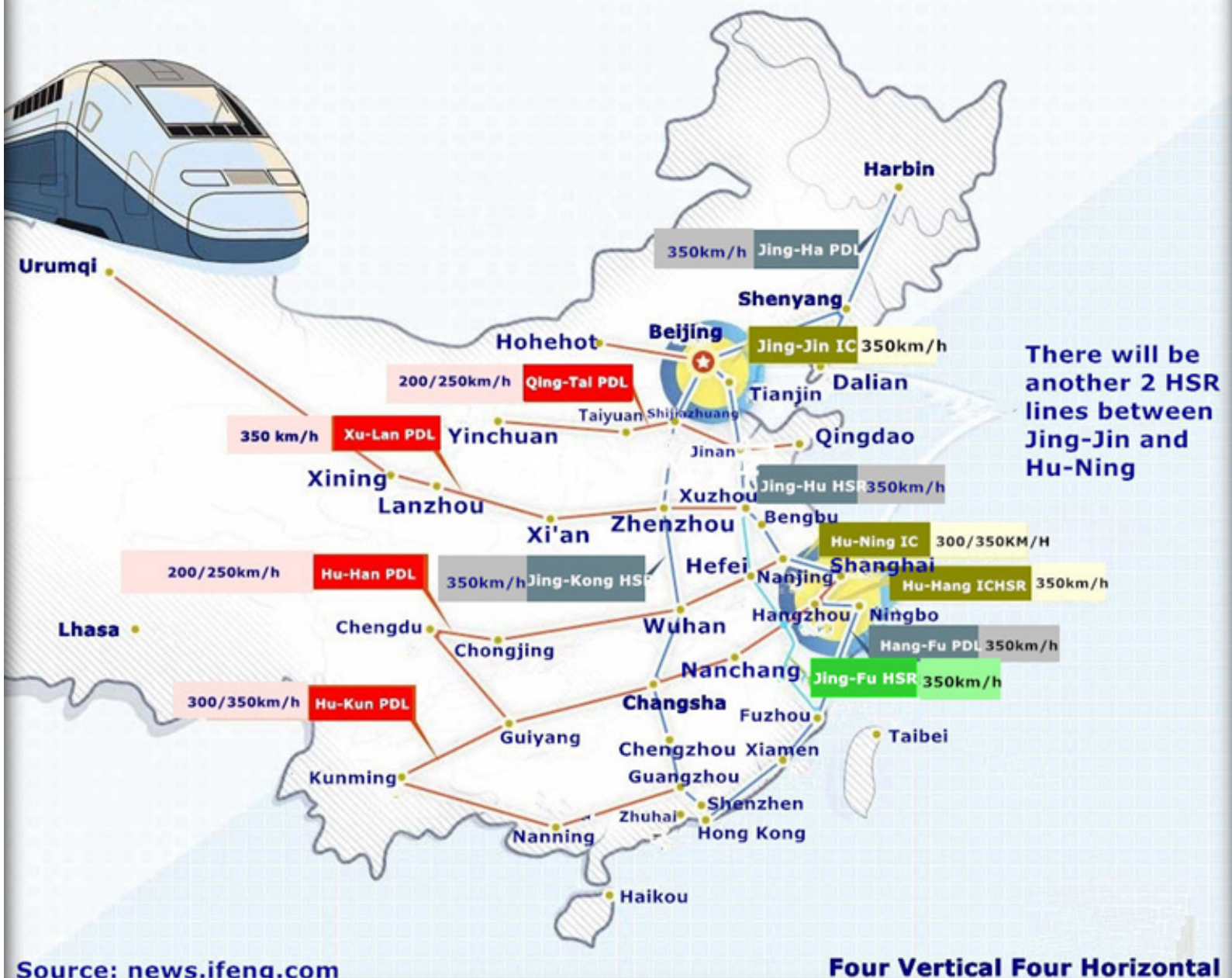

Source: news.ifeng.com

Four Vertical Four Horizontal

Source: http://m.guancha.cn/GaoTieJianWen/2014_07_22_249075

Figure 7. Four vertical \& four horizontal PDJs and HSRs

Through the following major train stations: Beijing Spark - Chengde South- Chaoyang North- Fuxin North - Shenyang / North / South - Tieling West- Siping East- Changchun West- Harbin West.

Shenyang-Dalian section passes through major stations: Shenyang North / South - Anshan West - Yingkou East Bayuquan - Dalian North.

Pan-Ying PDL passes through Panjin North-Haicheng West. A PDL linking Pan-North Korea plan is under way.

The Beijing-Harbin PDL involves the Jing-Shen PDL, Harbin-Dalian PDL and Pan-Ying PDL with a total length of about $1,612 \mathrm{~km}$ and design speed of $350 \mathrm{~km} / \mathrm{h}$., connecting the northeast and the areas within the Shanhai Pass.

Besides, Harbin-Dalian PDL has been opened on Dec. $1^{\text {st }}$, 2012. The Pan-Ying PDL opening and operation effected on Sept. $12^{\text {th }}, 2013$. China Railway Corporation officially launched the Beijing- Shenyang PDL construction project in Dec. $28^{\text {th, }} 2013$, planning to officially start on March $1^{\text {st }}$, 2014 and finish by the end of 2018.

\section{Hang-Fu-Shen PDL (South East Coastal PDL)}

Through the following major train stations: Hangzhou East - Ningbo - Taizhou- Wenzhou South, Fuzhou South Xiamen North - Shenzhen North, composed of Hang-Yong PDL, Yong-Wen railway, Wen-Fu railway, Fu-Xia railway and Xiamen- Shenzhen railway, connecting the Yangtze River Delta, Pearl River Delta and southeast coastal areas. In addition, HSR has been opened; D2286 (Shenzhen North-Shanghai Hongqiao) set off at 09:55 on Dec. $28^{\text {th }}$, 2013 from Shenzhen North station, and arrived at Shanghai Hongqiao station, taking only 12 hours and 17 minutes.

6.2.2. The HSR Network of Four Horizontal PDLs and HSRs

\section{$\mathrm{Xu}-\mathrm{Lan}$ PDL [12]}

Through the following major train stations: Xuzhou East Shangqiu - Zhengzhou East - Luoyang Longmen,- Xi'an North - Baoji South - Lanzhou West.

$\mathrm{Xu}-\mathrm{Lan}$ PDL contains the Xu-Lian PDL, Zheng-Xu PDL, Zheng-Xi'an PDL, Xi'an-Bao PDL, Bao-Lanzhou PDL with 
$1,606 \mathrm{~km}$ in length and a design speed of $250-350 \mathrm{~km} / \mathrm{h}$., connected to the northwest and east of China. And more, Zheng-Xu PDL began on Dec. $26^{\text {th }}, 2012$, is expected to open to traffic in 2015. Zheng-Xi' an PDL has been opened. Xi'an-Bao PDL opened on Dec. $28^{\text {th }}$, 2013. Bao-Lan PDL is expected to open by 2017.

Hu (Shanghai)-Kun HSR [13]

Through the following major train stations: Shanghai Hongqiao-Hangzhou East-Nanchang West-Changsha South-Guiyang-Kunming South with a total length of 2,066 $\mathrm{km}$ and design speed of $350 \mathrm{~km} / \mathrm{h}$, it is composed of Shanghai-Hangzhou PDL, Changsha-Kun PDL, of which Shanghai - Hangzhou and Changsha-Hangzhou sections are designed as a PDL at $350 \mathrm{~km} / \mathrm{h}$ grade and Chang-Kun section at $250 \mathrm{~km} / \mathrm{h}$ grade, connecting the east, central and southwest of China.

The Hangzhou-Changsha PDL was completed at the end of Dec., 2013. The Nanchang West - Changsha South PDL has opened on Sept.16 ${ }^{\text {th }}$, 2014. The Nanchang West Hangzhou East opened on Dec. 10 ${ }^{\text {th }}, 2014$. The plan across the board in June of 2014 began with joint adjustment and trial. The Hangzhou-Changsha PDL has been opened across the board by Dec. of 2014.

The Chang-Kun PDL started construction in March of 2010, Changsha South - Xinhuang West, was opened on Dec. $16^{\text {th }}, 2014$ and is expected to be completed by the end of 2015.

Qing-Tai PDL

Through the following major train stations: Qingdao North-Jinan West / East-Dezhou East Shijiazhuang-Taiyuan South, composed of Jiao-Ji PDL and Shi-Tai PDL with a total length of $906 \mathrm{~km} \mathrm{[14]} \mathrm{and} \mathrm{design} \mathrm{speed} \mathrm{of}$ $200 \sim 250 \mathrm{~km} / \mathrm{h}$ across the board, connecting Eastern and northern regions of China.

The latest developments: Jiao-Ji PDL was opened in July of 2008. Shi-Ji PDL within Shandong section officially started in Mar. $16^{\text {th }}, 2014$. Shi-Tai PDL was opened in April of 2009.

\section{$\mathrm{Hu}$ (Shanghai)-Han-Rong HSR}

Through the following major train stations: Shanghai Hongqiao-Nanjing South - Hefei - Hankou - Chongqing North - Chengdu East, composed of Shanghai-Ninbo intercity railway, He-Nin railway, $\mathrm{He}-\mathrm{Wu} \mathrm{PDL}$, Han-Yi railway, $\mathrm{Yu}-\mathrm{Li}$ railway and $\mathrm{Yu}-\mathrm{Li}$ railway.

\section{HSR Linking China Mainland with Taiwan}

Based on Arthur Thompson theory, China pursues a preemption action to deploy the HSR lines between China mainland and Taiwan. China Ministry of Railway ever proposed the construction of two HSRs linking mainland with Taiwan.

\subsection{Beijing-Taiwan HSR (Beijing - Fuzhou Section, Called Jing-Fu HSR)}

Beijing - Bengbu - Chaohu - Tongling - Hefei - Jixi - Mt. Huangshan - Shangrao - Mt. Wuyi - Nanping - Fuzhou Taipei, and the coastal city Putian set aside for cross-sea tunnel exit to Taiwan. (The program "Fuzhou through the Taiwan Strait tunnel to Taipei" lies at the unilateral idea stage of mainland).

\subsection{Kunming-Taiwan HSR (Kunming - Xiamen Section, Called Kun-Xia HSR)}

Kunming - Guiyang - Guilin - Chenzhou - Ganzhou Longyan - Xiamen - Kaohsiung, Zhangzhou and Quanzhou Xiaocuo port keep reserved for cross-sea tunnel outlet to Taiwan. (The Xiamen-Kaohsiung section is the same as that of Beijing-Taiwan HSR will not be implemented until both sides of the Taiwan Straits reach a common agreement). 


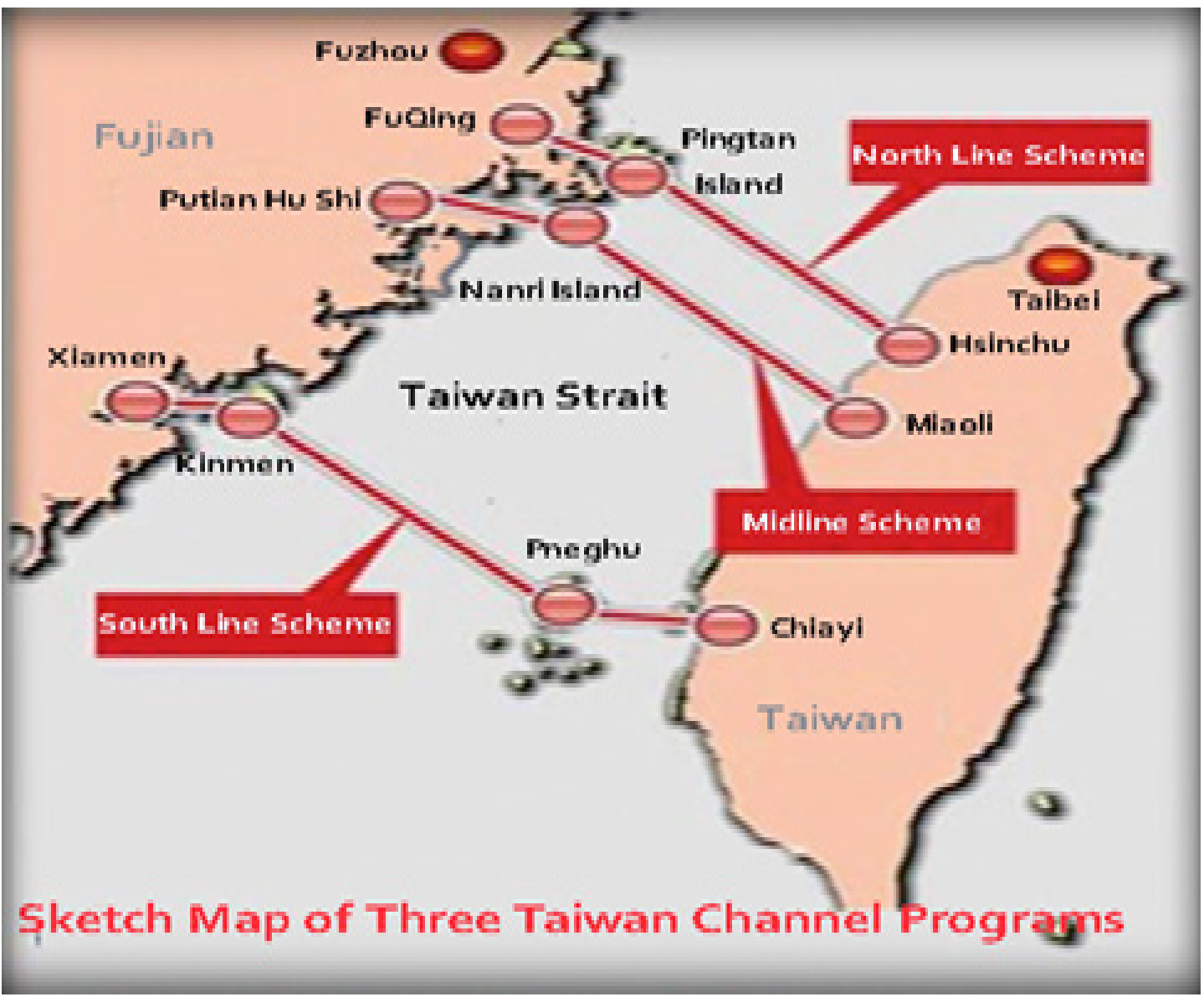

Source: http://blog.sina.com.cn/s/blog_5e9bd7250100le29.html

Figure 8. Three choices reserved for cross-sea tunnel outlet to Taiwan.

\section{Analysis and Explanations for China HSR at Home}

\subsection{Shaping the HSR Network of Four Vertical and Four Horizontal PDLs and HSRs}

China has been a good momentum of HSR development; it undoubtedly will also reinforce the confidence in promoting China HSR overseas.

Along with the taking shape of the "four vertical and four horizontal" fast railway network as the main framework, China HSR is going abroad. On Jan. $29^{\text {th }} 2015$, Mr. Sheng Guangzu, general manager of China Railway Corporation (CRC) at the annual working conference revealed that 2015 will be to expand the overseas market for high-speed railway construction as the focus, and vigorously promote the railway walking out of China, and further enhance the international competitiveness of China HSR. In short, "the railway goes out of China to achieve a new breakthrough, the total international level of the China Railway Corporation (CRC) will be significantly improved."

CRC intends to take advantage of the below aspects of management, technology, resources as well as a leading role at the enterprise level so as to expedite to build cooperation platform at the enterprise level, forming a coordination mechanism to avoid vicious competition. But to what the results will it bring, it is difficult to draw conclusions.

CRC informed of that as of the end of 2014, China's high-speed railway operating mileage exceeded $16,000 \mathrm{~km}$, 2015 will break through $18,000 \mathrm{~km}$, [15] the "four vertical and four horizontal" fast railway network as the backbone of the HSR network has started construction and most of the sections have opened to traffic, leaving a small amount of them to be finished by the end of 2015 .

CRC also said that as the HSR capacity continued to improve so as to significantly speed up the whole society flow, logistics flow, significantly shorten the travel time of passengers and that the total cost of social logistics has been reduced effectively.

After having opening the HSR network, people travel around in a substantially compressed time. For instance, after the opening to traffic of Guiyang-Guangzhou PDL, the train running time with 20 hours has been shortened to 4 hours; Lan-Xin PDL, i.e., Lanzhou to Urumqi train running time from 18 hours 30 minutes to 9 hours. With the sustained and rapid growth of traffic volume, to save the social time costs via HSR will accomplish significantly. And it can also effectively alleviate the long-term tension of freight. Since the Chang-Huai section within Shanghai-Kunming HSR has been opened to traffic, it is not only conducive to the separate traffic operation of passenger and freight in Shanghai-Kunming railway channel to alleviate the pressure 
of passenger carriage, but also lift the annual cargo capacity 140 million tons. And the released cargo capacity laid a solid foundation for launching both the Nanjing East- Zhuzhou North Cross Railway Bureau Freight Express train and fast freight train $120 \mathrm{~km} / \mathrm{h}$. Relying on the Hu-Kun, Xiang-Pu, Jing-Kowloon, Gan-Long railway trunks, it accelerated the formation of Shanghai, Ningbo, Xiamen and Shenzhen HSR-Sea route transport network.

In addition, as the role of HSR in the comprehensive transportation system continued to improve, HSR sped up the whole flow in society and logistics flow significantly, reduced costs effectively, improved business efficiency and increased the quality of economic development. According to statistics, China has opened to traffic and operation and left a space of annual cargo capacity of 230 million tons for the transport of goods. Compared with 2007, the 2014 the national railway freight volume increased by 681.54 million tons, up $21.8 \%$. [16]

HSR can not only bring the direct impact of the above, accelerate industrial restructuring and upgrading, reduce social logistics costs, but also optimize the industrial structure adjustment.

As such, Mr. Yang Chuantang, Communications Minister, for the first time at the annual CRC meeting praised, "The railway makes an important contribution to the steady growth, promoting reform and structural adjustment. And the railway development plan will be an important chapter in the $13^{\text {th }}$ Five-Year National Communications Plan under being drafted."

\subsection{Establishing Coordination Mechanism at Enterprise Level}

Before, China HSR was expected to obtain an overall construction + equipment project to go to sea in Mexico, unexpectedly this project changed and its bid aborted finally. China Railway Construction (601186), China South Railway (601766), etc. these companies recently restart bidding for Mexico.

Prior to going to sea, the domestic enterprises also have to take the Baotuan spirit into considerations, no longer repeat the overseas vicious competition situations between China North Railway and South Railway as well as amongst other central enterprises. Mr. Sheng Guangzu, general manager of CRC said, "China Railway Corporation will give full play to the below advantages, e.g., management, technology and resources and the enterprise level, China will accelerate the formation of the "going out" inter enterprise information sharing and coordination mechanism in which the railway survey and design, construction, equipment manufacturing, signaling and communication enterprises do participate, well co-ordinate the domestic resources and foreign markets so as to achieve the mutual benefits, win-win results, and enhance the competitiveness of the whole industry chain in China HSR.

This coordination mechanism comes timely, but there are also railway insiders said, "China Railway Corporation initiates the communication platform, the early intention is to coordinate, yet the effect is still difficult to forecast. Before, the Ministry of Railways was able to dictate to organize the 18 related companies to work on the overseas railway projects. Today, however, China Railway Corporation itself has become one of the central enterprises, CRC is parallel to China Railway (601390), China Railway Construction Corporation, China South Railway, China North Railway (601299) etc., the coordination amidst them seems more difficult than in the past.

Apart from the coordination of platform, $\mathrm{CRC}$ also intends to urge the construction of the railway interconnectivity with the neighboring countries. Recently it is to focus on Sino-Laos, Sino-Thailand railway projects, while actively promoting the Hungarian-Serbia railway, Russia Moscow-Kazan HSR,

Tanzania-Zambia railway projects, and strives to complete the goal as scheduled.

In addition, CRC also intends to integrate railway international container transportation business, strengthen the domestic and international business network and construct the cross-border railway logistics.

\section{International Deployment of China HSR}

\subsection{China Differential Philosophy of Trading HSR for Local Resources}

According to Arthur Thompson theory of differentiation, China adheres to a differential principle that to build any cross-border HSR line shall supply HSR projects with capital, technology, equipment to build them, after the completion of construction, the countries along the HSR line will get involved in the operations. In this process, China will negotiate with relevant countries and replace the local resources with the construction costs of HSR. [17]

As of the end of 2013, China HSR operation mileage reached $11,028 \mathrm{~km}$, the HSR scale under way $12,000 \mathrm{~km}$ all over the world, China has become a country with the longest operating mileage and largest scale and has formed a preliminary network of HSR. According to the statistics of International Union of railways, as of Nov. $1^{\text {st }}, 2013$, the total HSR operating mileage of the rest of the world arrived at $11,605 \mathrm{~km}$, a scale under way $4,883 \mathrm{~km}$, planning to build 12, $570 \mathrm{~km}$, [18] China HSR physical volume was equal to that of the rest of the world. Once China HSR network has been built, the traditional railways will release a huge logistics capacity, the two major bottlenecks of passenger flow and freight logistics will be eased. The HSR construction will pull the demands for basic industries such as steel, cement, trains, etc., when China's real estate and other fixed assets investment are declining, the HSR will play a vital role of pulling the essential industries. In 2014, China's HSR operating mileage was equivalent to the total sum of the rest of the world, and also ranked $1^{\text {st }}$ all over the world. 


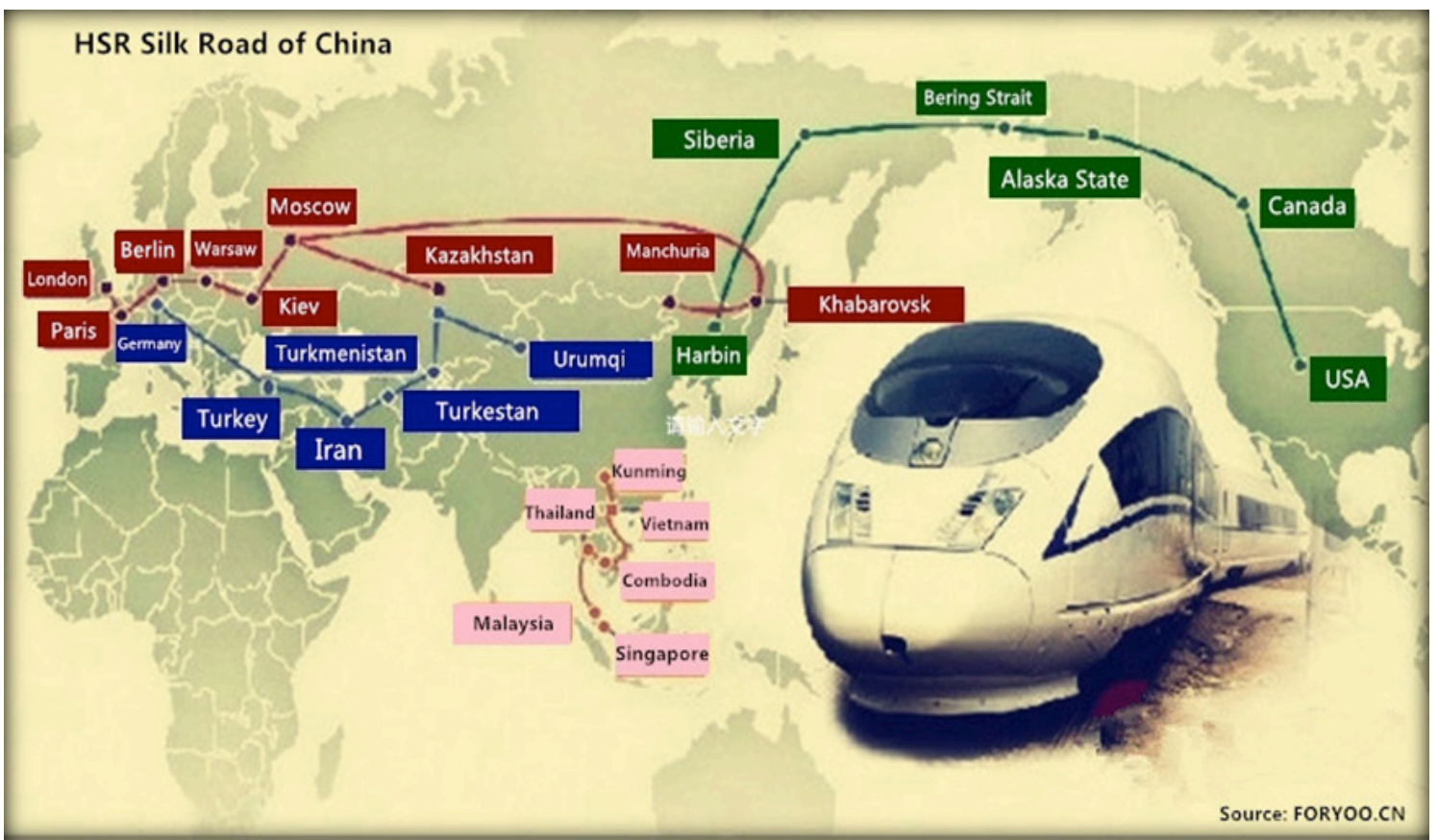

Source: http://blog.sina.com.cn/s/blog_498f37c70102vujj.html

Figure 9. HSR Silk Road of China

According to China Railway Ministry and International Union of Railways, as of November of 2013, the statistical data showed as follows:

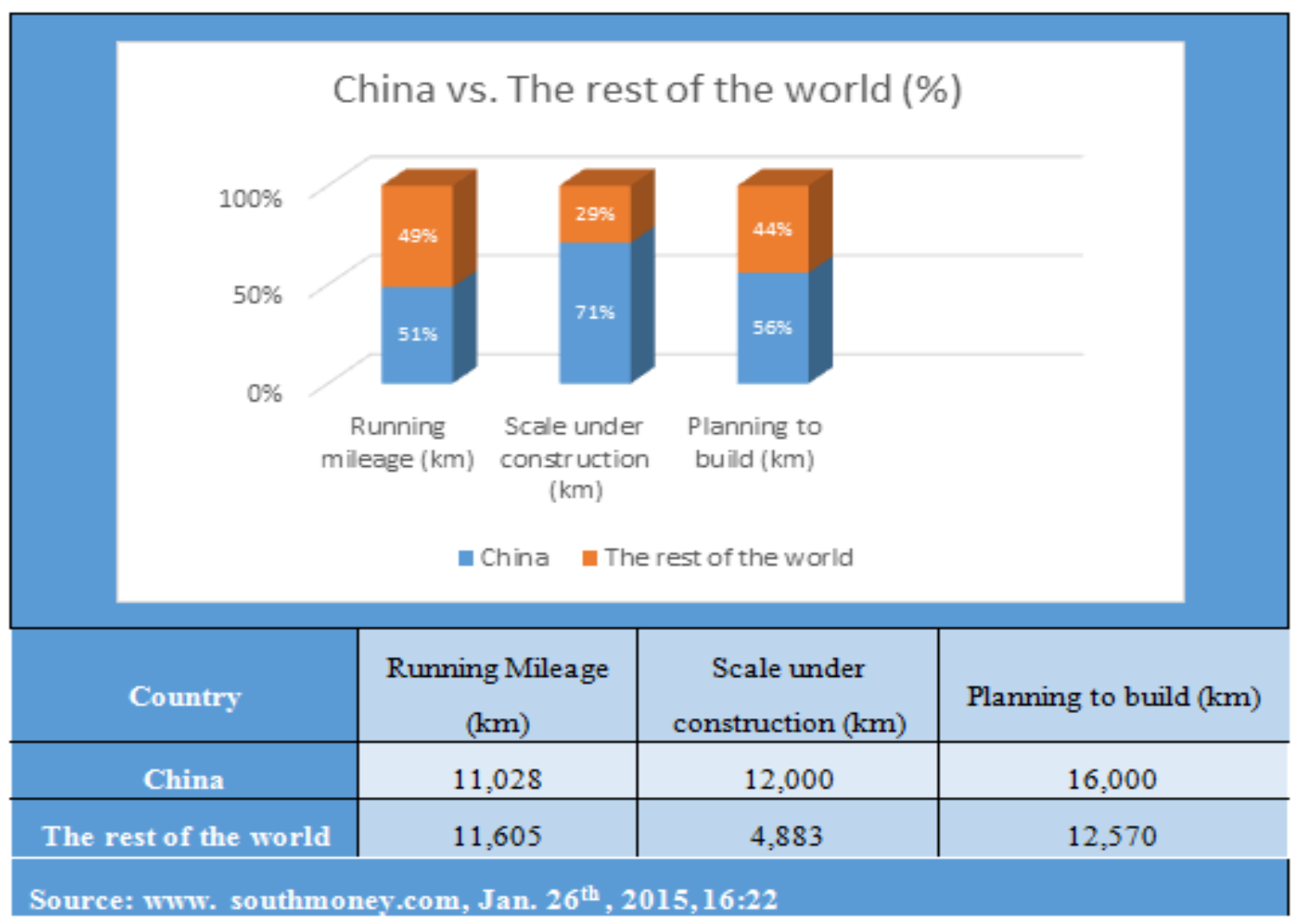

Figure 10. Making Comparisons China vs. the rest of the world

Based on Arthur Thompson theory of obtaining advantages, China makes full use of capital, advanced technology, low cost, large manpower, etc. to execute HSR construction abroad. China international HSR network shall be composed of the four PDL trunks as follows: the Eurasian, Central Asian, Pan-Asian and Asia-North American HSR network. 


\section{HSR Scale admist Global Giants}

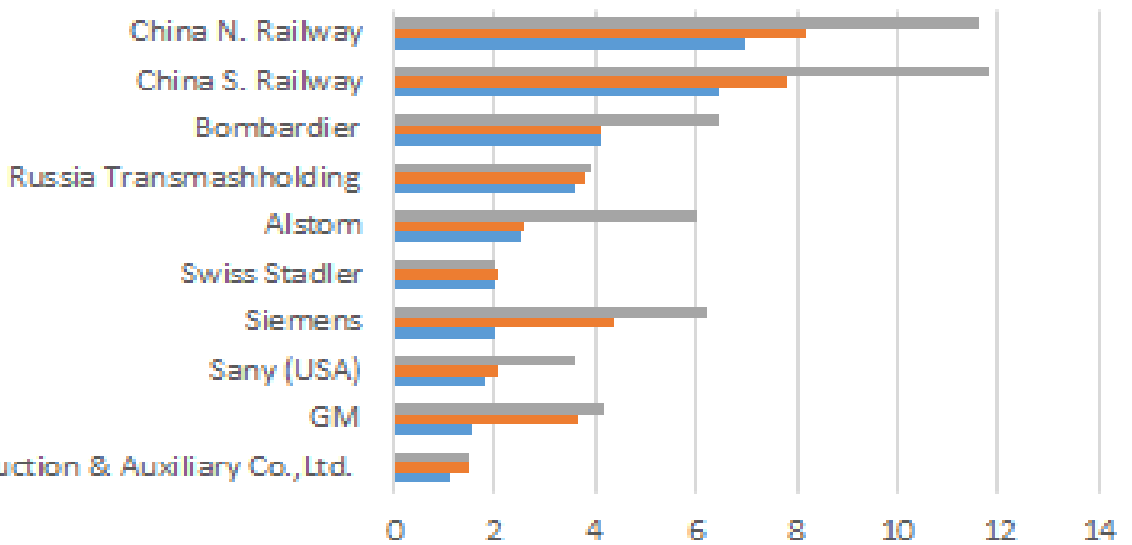

ather business revenues (Billion euro) a Other business railway (Billion euro)

- Tram manufacturing (Billion euro)

\begin{tabular}{|l|c|c|c|}
\hline & 6.5 & 7.8 & 11.8 \\
\hline China North Railway & 7.0 & 8.2 & 11.6 \\
\hline China South Railway & 4.1 & 4.1 & 6.5 \\
\hline Bombardier Transportation & 3.6 & 3.8 & 3.9 \\
\hline Russia Transmashholding & 2.5 & 2.6 & 6.0 \\
\hline ALSTOM Transport & 2.0 & 2.1 & 2.0 \\
\hline Swiss Stadler & 2.0 & 4.4 & 6.2 \\
\hline Siemens Transportation & 1.8 & 2.1 & 3.6 \\
\hline Sany Division (USA) & 1.6 & 3.7 & 4.2 \\
\hline General Motor & 1.1 & 1.5 & 1.5 \\
\hline Spain Railway Construction-Auxiliary Co., Ltd. & & \\
\hline \hline
\end{tabular}

Source: http://www.cet.com.cn/cjpd/jjsj/1126883.shtml, Die Welt Observation Network, Quelle: SCI VERKAHR

Figure 11. Making comparisons HSR scale amongst global giants

\subsection{Eurasian HSR}

China has long been aware of the importance of developing Central Asian resources and promoting the development of the Central Asian regions, and has begun to plan for the construction of Central Asian and European railways many years ago. Whether or not it is in perspective of the commercial interests or strategic considerations, the construction of a high-speed railway across the Eurasian continent irresistibly attracts China. Compared with the conventional railway, the HSR can transport large quantities of goods and materials in a very short period of time. This will provide China with great convenience to import crude oil and minerals from Central Asia, while China's exports of goods will be faster and more convenient to arrive in the Middle East and European markets.

The China National Development and Reform Commission has planned for involving multiple railway of the Eurasian Continental Bridge and the new Silk Road, of which there will be to construct the Korla-Nagel railway, General Temple (near Urumqi)- Hami- Ejin (Inner Mongolia), two lines towards the East can further reach the coastal areas of eastern China. And the Yinchuan-Xi'an's rapid railway project proposal has been approved; there has 
a PDL directly from Yinchuan to Xi'an, and even Zhengzhou afterwards. Furthermore, to leave for Europe from the east to the west of China, people can either take the northern line Hami-General Temple or ride the Long-Hai line and Lan-Xin line, or catch the Korla-Golmud line. Experts involved in China HSR project said, "China is negotiating with the 17 countries on the construction of the Asian and European high-speed railway network." There have been the plans to build three HSR lines throughout the next decade, linking Asia with Europe. By then, the HSR train shall drive at more than 200 miles per hour from London to Beijing for only two days, even taking shorter time than the domestic train running time within China which couldn't be imagined in the past. These 3 planned HSR lines shall be the one extends northward through Russia to Germany and joins the European railway system; another one extends southward to connect the Southeast Asian countries such as Vietnam, Thailand, Myanmar and Malaysia, Singapore, etc.; the $3^{\text {rd }}$ one will connect China and the United Kingdom, India as well as Pakistan, respectively. China, Iran, Pakistan and India are negotiating for laying the HSR infrastructure projects, while the Southeast Asian route has been started in Yunnan province. In terms of engineering standards, China hopes that all lines would be consistent with the domestic high-speed railway criteria, the Vietnamese party has expressed its agreement, but other countries are still under negotiation. [19]

\subsection{Pan-Asia HSR}

Pan-Asia HSR refers to a HSR construction project connecting China Yunnan province with the Southeast Asian countries such as Vietnam, Laos, Thailand, Myanmar, Malaysia, Singapore, etc., which comprises three HSR lines: namely, the east Sino-Vietnam one, west Sino-Myanmar one and mid Sino-Laotian-Thai one.

At present, China HSR going out strategy is divided into four directions, the first is the Chongqing-Xinjiang-Europe railway which has been built from Chongqing via Urumqi, Kyrgyzstan, Uzbekistan, Iran and Turkey to Europe; the second is the railway from Central Asia via Iran and Turkey to Europe, the third is the Sino-Pakistan railway from Kashgar to Gwadar Port; The fourth is the Pan-Asian railway from China Yunnan via Vietnam, Laos, Thailand, Myanmar, Malaysia to Singapore.

In reality, apart from the Chongqing-Xin-European railway, the biggest possibility of being completed first may well be the Pan Asian Railway before other three HSR lines, and Pan Asia railway is expected to be broken through from Sino-Thailand route, while the east Sino-Vietnam and west Sino-Myanmar are ground to a halt, the midline of Sino-Laos-Thailand turns out to be more and more possible.

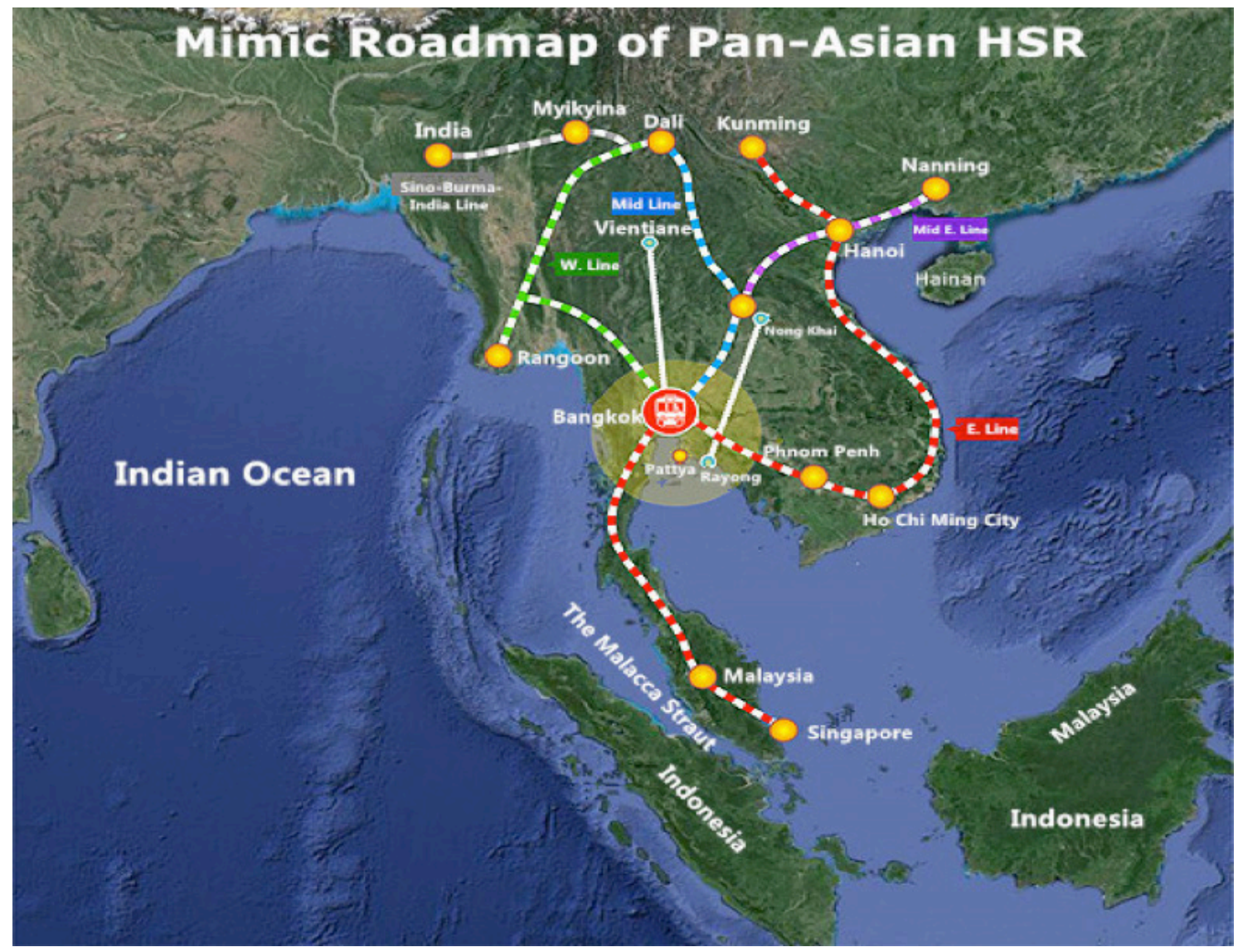

Source: http://tuku.cscav.com.cn/index.php?m=picdetail\&pid=265214928

Figure 12. Mimic roadmap of Pan-Asia HSR 
China is promoting the all-round interoperability and infrastructure construction within the Greater Mekong sub regions, accelerating the development of regional railway union, economic corridor and other hardware construction; jointly planning the future direction of the Greater Mekong sub regional economic cooperation, on the basis of the strategic framework for the next new decade, building a more open sub regional cooperation, of which it is undoubtedly to focus on the regional railway union and cooperation of other aspects of the hardware construction.

China will participate in the construction of two sections of double track railway in Thailand with a total length of $133 \mathrm{~km}$, a total investment of 350-400 billion baht (about RMB 71-82 billion RMB Yuan.) [20] Those tow railway projects are expected to connect Vientiane via the Sino-Laotian railway, which will link the Yuxi- Mohan railway (located in China Yunnan province, recently obtained the approval from the National Development and Reform Commission.)

Therefore, once the Sino-Thailand railway cooperation has been implemented, which means that the Pan-Asian Railway sections outside China under planning shall have made a significant progress, which will then lay an important foundation for the subsequent interconnectivity of Sino-Laos-Thailand-Malaysia-Singapore HSR, and those railway equipment enterprises are expected to get more development opportunities.

\subsection{Central Asia HSR}

The Central Asia HSR begins with China Urumqi via Kyrgyzstan, Uzbekistan, Iran and Turkey to Europe, including Berlin, Paris and London.

To build an HSR network linking the western China with the Central Asian countries is being planned and may eventually connect the European railway network. After the completion, the Sino-Central Asian railway shall operate at speed up to $200 \mathrm{~km} / \mathrm{h}$, linking China Urumqi and Central Asian countries such as Kazakhstan, Uzbekistan, Turkmenistan, etc. and the Central Asian HSR may well eventually be connected with the European Railway network. The Central Asia HSR network plans to erect 3 railway lines or spend 10 years to complete them, and three HSR lines shall be incorporated into the Eurasian transportation within the forthcoming 10 years.

There are two main objectives of the construction of the Sino-Central Asian HSR network: one is to promote the economic development of the western regions of China, another one is to facilitate the transport of natural resources, which is expected to be completed in the next decade, the HSR program will be estimated that there will be millions of people to remove to the West China.

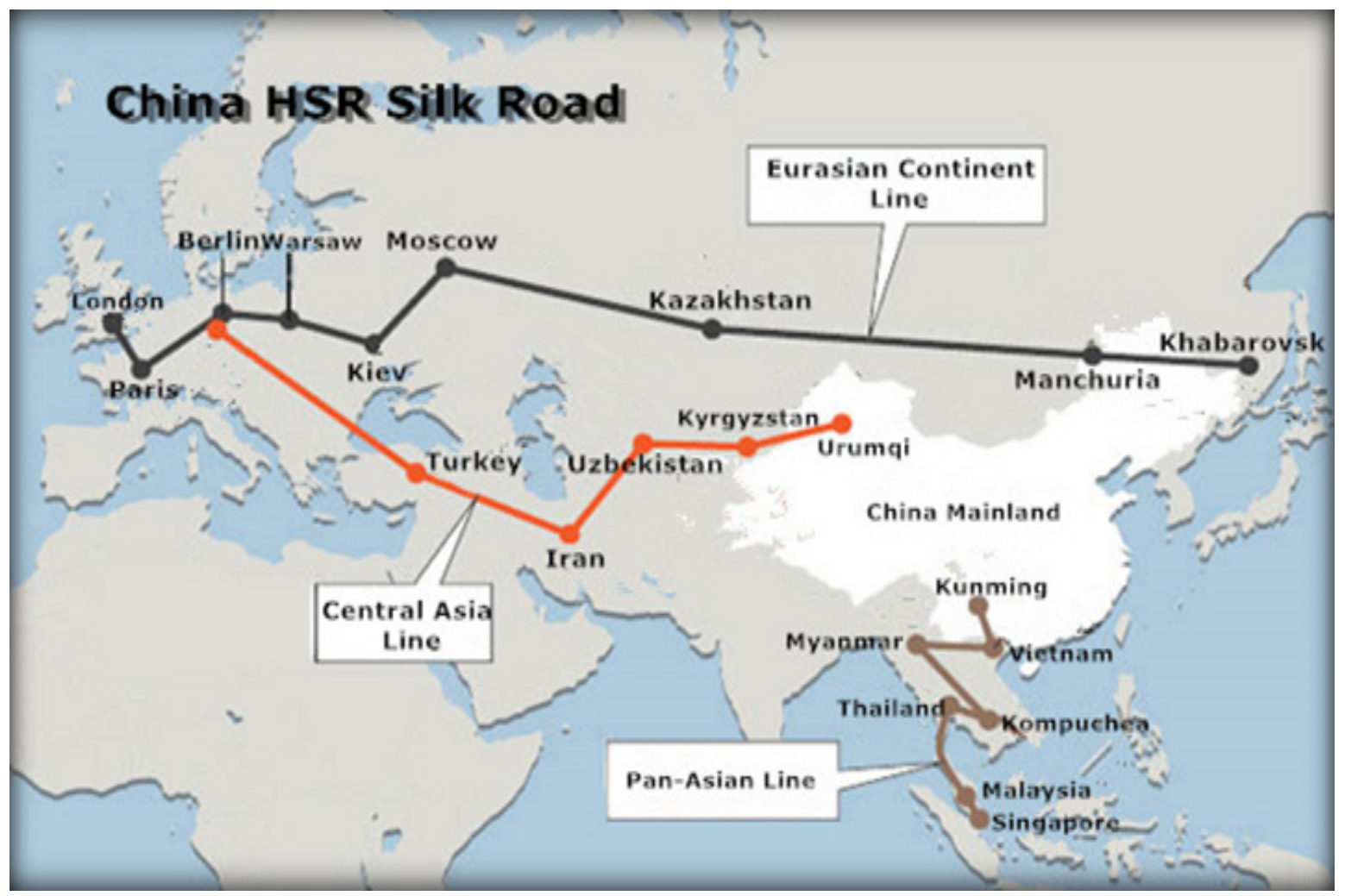

Source: http://www.homemom.ca/album/photo.php?id=7847

Figure 13. China HSR Silk Road 
The goal of the Sino-Central Asian HSR may eventually be connected with the European railway network, when passengers from the London King's Cross station will ride for only 48 hours to reach Beijing. Within the next 10 years, China high-speed railway MU (Multiple Units) can operate at a speed of up to $350 \mathrm{~km} / \mathrm{h}$ in Eurasian continents. The $2^{\text {nd }}$ program of China and other countries building a Eurasian railway network is to pass through Russia into Germany and then connect the European railway network, the $3^{\text {rd }}$ program is to pass through Vietnam into Thailand and then connect Myanmar, Malaysia and Singapore with the Sino-South Asian HSR. After the grand programs have been completed, passengers will be able to cover the 5,070-mile journey from London to Beijing for only 48 hours and the 6,750-mile one from London to Singapore for only 72 hours. [21]

At present, China, Iran, Pakistan and India are holding discussions on the HSR pavement. China and Russia have reached a consensus on the HSR line across Siberia. With the introduction of fast and high-speed railway transportation, people will build mines, factories and business centers in the West China. In fact, to promote the HSR program is not just China, the India government is also to welcome and support the HSR project in Central Asia.

\subsection{Asian-American HSR}

Asia-America HSR pertains to a forward high-speed railway linking Asia and America continents, setting off from the northeast of China straight ahead the north, arriving in the Bering Strait via Siberia, by means of constructing a tunnel across the Pacific, reaching Alaska from where getting to Canada, eventually arriving in the United States with a total length of $12,000 \mathrm{~km}$. [22]

\subsubsection{The Construction Plan}

China intends to cooperate with Russia, Canada and the United States for the construction of an HSR line across the Bering Strait with over $10,000 \mathrm{~km}$ in length, connecting the two continents of Asia and America. There should be a principle that to build the cross-border HSR line, China shall supply HSR with the capital, technology, equipment to build, after the completion of construction, the countries along the HSR line will get involved in the operations. In this process, China will negotiate with relevant countries and replace the local resources with the construction costs of HSR.

\subsubsection{The HSR Function}

Building a railway across the Bering Strait needs to dig about $200 \mathrm{~km}$ of the undersea tunnel. Preliminarily estimating, the whole line shall total about $13,000 \mathrm{~km}$, if built, it will eventually connect Beijing, New York and even Washington D.C. It will no longer have to fly from China to the United States, and then to ride the HSR line can watch the tourist attractions along the way of varied countries, and in accordance with a designed speed of 350 $\mathrm{km}$, and Chinese travelers are expected to arrive in the United States for less than 2 days. [23]

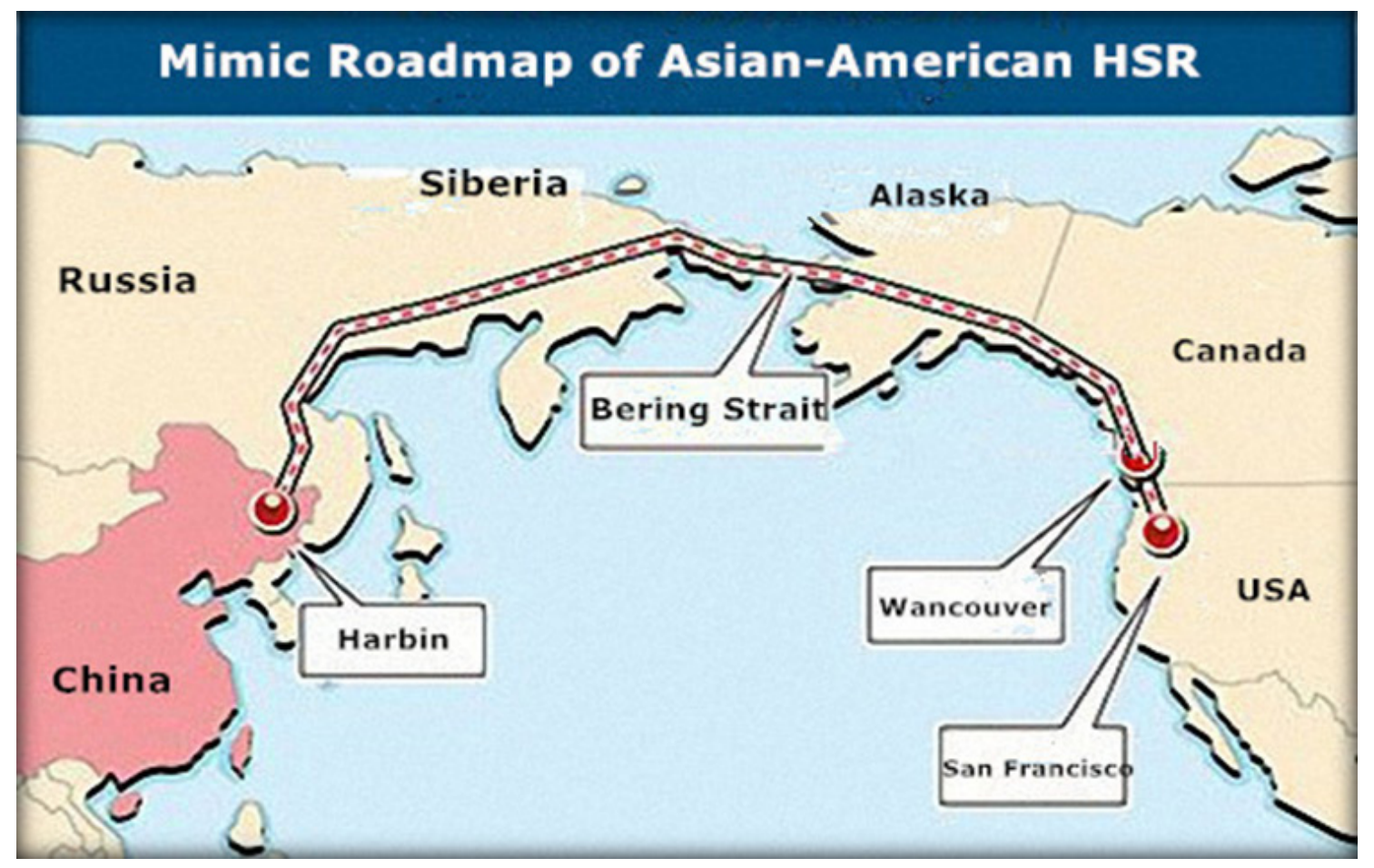

Source: http://liuxue.zjchuguo.com/news-4008.html

Figure 14. Mimic Roadmap of Asian American HSR 


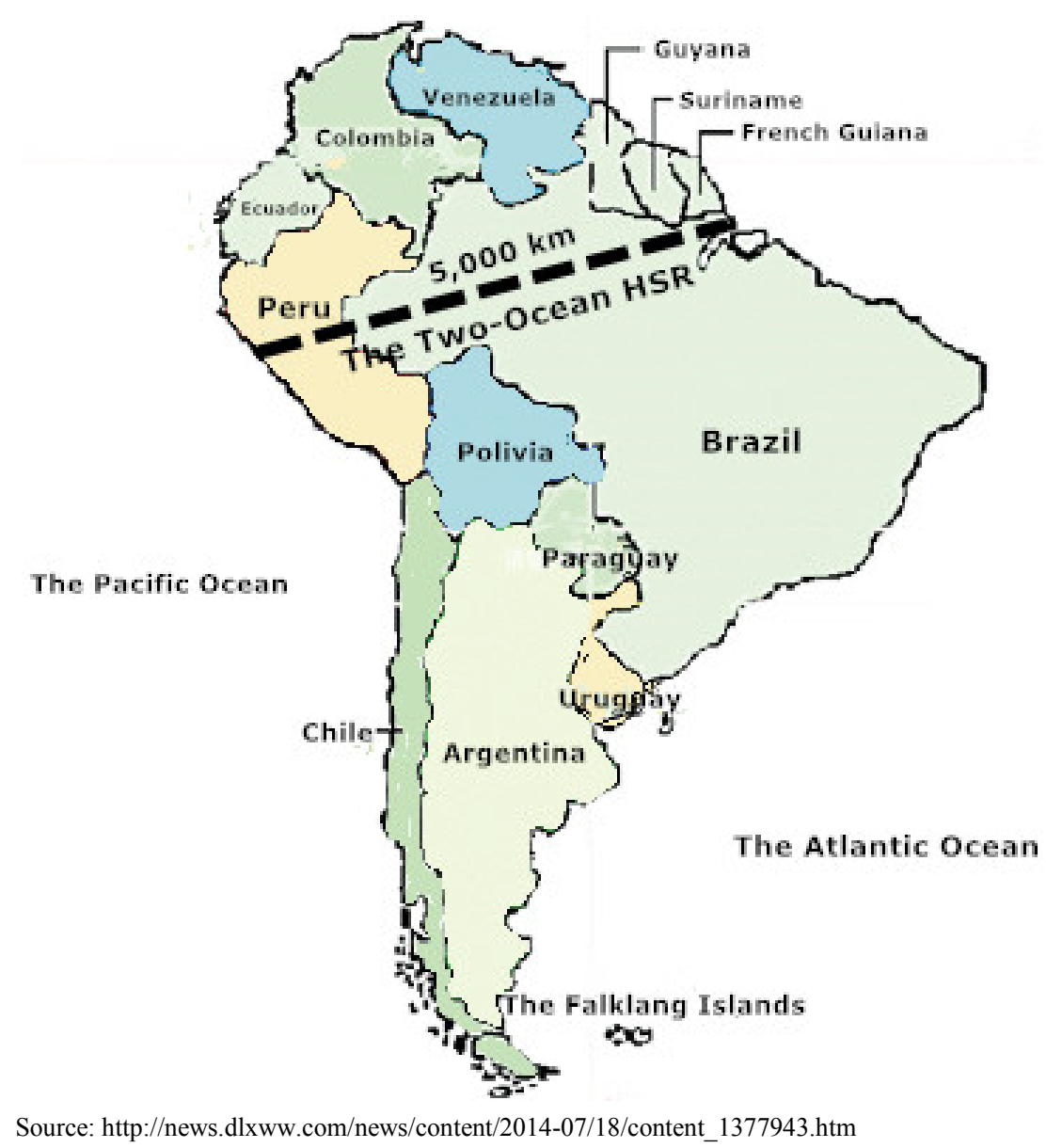

Figure 15. The Pacific-Atlantic Ocean HSR

\section{Pacific-Atlantic Ocean HSR}

The Atlantic-Pacific Ocean railway will be a huge and complex project, which is of importance for china's economic growth strategy.

On July $16^{\text {th }}, 2014$, China, Brazil and Peru carried out the Pacific and Atlantic Railway (i.e., The Two Oceans Railway) Cooperation and issued a joint statement. Brasilia's president Humala said, "Peru is willing to work together with China and Brazil to build the two oceans railway for the benefit of the peoples of the three countries." The Two Oceans Railway refers to a railway construction project that passes through the South American continent, connecting both the Pacific and Atlantic coasts. The South America's Two Oceans Railway is from the east coast of Peru to the west coast of Brazil, about 5,000 km with at least $\$ 10$ billion US dollars. [24] Once built, it will be the first railway across the South American continent in history of Latin America, and become the backbone of the network of Latin America. Some Latin American strategists almost dream of the grand target of constructing the Two Oceans Railway for ages. The construction of the Atlantic and Pacific Ocean railway is not proposed today. According to the BRIC countries during the summit meeting in accordance with the proposed scheme, China, Brazil and
Peru will organize a working group to carry out the overall cooperation, including planning, design, construction, operation, etc.

\section{Analysis and Explanations for China HSR Abroad}

The Asian Times article said, "But it is not easy to build a railway, because China's construction of HSR at least faces the following several aspects of the challenges: The one is a huge amount of money that cannot be raised. The funds needed to build the Eurasian high-speed railway will be an astronomical figure, not the government of China may well be loaded alone. Even if the countries and regions along the ways of OBOR shall be willing to provide part of the funding for the Eurasian railway, but still cannot meet the giant needs. Another one is the railway operations will be a problem. For example, how to manage and operate the transnational high-speed railway system will be a great challenge for the Eurasian railway crossing over a dozen countries. If the countries along the ways of OBOR cannot agree on the Eurasian railway operations, it won't mention the follow-up cooperation. The $3^{\text {rd }}$ one is the technical problems that still cannot be solved. Eurasia continent is the 
largest one in the world, of where the geological conditions might be the most complex along the Eurasian railway full of either alpine valleys or deep rivers and lakes, to build such a high-speed railway through so much complex geological environments in technology is to face plenty of enormous challenges. [25]

\section{Suggestions for OBOR Economic Expansion Strategy}

\section{Strengthening the Policy Communication}

The countries along the ways of OBOR may communicate on the economic development strategy; while differences reserved so as to seek common ground, in line with the principle of consultation, it is to jointly work out the plans and measures to promote regional cooperation, and open "green lights" for the regional economic integration at levels of policy and law.

\section{Enhancing Interconnectivity of the HSR Silk Road}

The Shanghai Cooperation Organization (SCO) is negotiating a traffic facilitation agreement that shall be signed and implemented as soon as possible; transport channels will be opened from the Pacific Ocean to Baltic Sea in the near future. China is willing to work with all parties to actively explore the feasibility of improving cross-border transportation infrastructure, and gradually form a transportation network linking East, West and South Asia so as to furnish the economic development of all countries and personnel exchanges with convenience.

\section{Setting up China HSR Standards}

The competition of China HSR standards is the most important challenge during the future international process. After having received China HSR standards, China incurred the "de-standardize" in Mexico, which reflected the deep interests behind the HSR standards and the Chinese standards may not well go abroad. In 2015, China Railway Corporation will actively promote the establishment of technical standard system for railway industry, accelerate the internationalization process in HSR technical standards, perfect railway intellectual property management mechanism and improve the Chinese standards of MU intellectual property layout. In the field of HSR equipment, China will accelerate the speed of $350 \mathrm{~km}$ China standard MU research and development, make sure to complete the following tasks, e.g., the prototype assembly, type test, the use of assessment in 2015. At the same time, China will speed up the development of $250-\mathrm{km}$ Chinese standard MU and form the Chinese standard MU series products.

\section{Strengthening the Circulation of RMB}

China, Russia and other countries have not only had good cooperation in local currency settlements and made gratifying achievements, but accumulated rich experiences. It is necessary to promote these good practices. If all the countries achieve the currency exchange and settlements under current and capital accounts, it can greatly reduce the cost of circulation, enhance the ability to resist financial risks and improve the international competitiveness of the local economy.

\section{Increasing People Intercommunication}

The diplomatic relations between country and country lie in the intimacy between people and people. To do a good job in the above-said fields of cooperation, the peoples of all countries must support and strengthen the friendly exchanges among them, only if we enhance mutual understanding and traditional friendship, and can we lay a solid foundation for public opinion and social foundation for the developing the regional cooperation.

\section{Conclusions}

To sum up, this article does a panorama research on China OBOR and all-round deployments for the next decade.

Firstly, OBOR fits in Arthur Thompson growth strategy well. China OBOR benefits from Arthur Thompson growth strategy theory such as competitive advantages, preemption action, differentiation action, etc.; in the meantime, OBOR is a typical combination of the east and west thinking.

Secondly, OBOR might eventually form a closed loop on both land and sea routes in the globe;

Thirdly there are 23 provinces, municipalities directly under central government and autonomous regions that have started a comprehensive OBOR deployment;

Fourthly, China possesses 4 financial institutions (AIIB, SRF, SCONDB and BRICDB) to furnish the countries and regions along the way of OBOR with capital and money for infrastructure construction (HSR, highway, energy resources development, etc.);

Finally, there have already been four vertical and horizontal PDA and HSR network at home, and China works out five international HSR line network (Eurasian HSR, Central Asia HSR, Pan-Asia HSR, Asia-America HSR, Atlantic-Pacific Ocean HSR) abroad as well.

But there are still main problems left to be resolved, for instance, how and when does China strengthen the policy communication, enhance interconnectivity of the HSR Silk Road, benchmark China HSR, increase people intercommunication together with the relevant countries and regions efficiently and effectively?

\section{REFERENCES}

[1] Arthur Thompson, Strategic Management, [B], Beijing, Peking University Press, Science \&Culture Publishing House (H.K.), 2001, 2 $2^{\text {nd }}$ Ed.,PP.175-178.

[2] He Ailian, China 2014 GDP Ranked $2^{\text {nd }}$ and Broke through \$1Trillion US Dollars, [N], South Daily, 
http://www.askci.com/finance/2015/01/21/15414demh_all.sh tml. 01/21/2015.

[3] Qiu Guanshi, Last year, China, Imp. And Exp. Trading Volume Amounted to $\$ 4.16$ trillion dollars and Became The Largest Trading Nation in the World, [W], http://gb.cri.cn/42071/2014/03/07/4865s4452754.htm, 09:15:20, 03/07/2014.

[4] Gao Jiangbo, 2015 "One Belt and One Road" Track Transportation Development and Cooperation Summit Forum held in Shanghai, http://news.swjtu.edu.cn/ShowNews-1003 2-0-1.shtml, 09/04/2015.

[5] Zheng Jianli, Applying Finance to Analyzing the Significance for One Belt and One Road, [W], http://www.doc88.com/p-8038565120399.html, 04/25/2015.

[6] Xinjiang Metropolis Daily (Urumqi), Gwadar: Several Important Routes, http://news.163.com/15/0421/10/ANNGGK2Q00014AED.ht $\mathrm{ml}, 0: 15: 00,04 / 21 / 2015$.

[7] Cheng Yong, Xinjiang Three Bases and One Channel to Build the Energy Silk Road, [R] http://www.chinanews.com/cj/201 5/05-24/7297121.shtml, 11:47, 05/24/2015 24.

[8] Han Jie, Xiong Zhengyan, 57 countries from Five Continents to Become Sub Investment-Intended Founding Members, [W], www.news.xinhuanet.com, 19:23:35, 04/15/2015.

[9] Tencent, The BRICs Countries Willing to Found the BRICs Bank, [W]

http://www.gazx.org/content/2014-7/16/2014716163344590 02.htm, 07/16/2014.

[10] Baidubaike, The Four Vertical and Four Horizontal PDLs and HSRs Planning for China Railway, [W], http://baike.baidu.com/link?url=OdcJVmijdUJjJW5xRrceY StD-hHsCDXMoZkNERJFz0vKwUn5PXT5CvenbosyzrBv ${ }^{-}$ NVd1QRHYVpCSLHetFID1_

[11] The National Development and Reform Commission of the people's Republic of China: the Long-term Railway Network Program (Adjusted in 2008), [R], http://zfxxgk.ndrc.gov.cn/PublicItemView.aspx?ItemID $=\{\mathrm{eb}$ 9d2128-3267-4c3d-bad5-309ca7c037a2\}, 03/09/2014.

[12] High-Speed Railway Forum, Xu-Lan PDL, [W], http://www.51 crh.com/thread-123599-1-1.html, 16:50:02, 01/05/2015.

[13] National Railway Bureau, the National Railway Bureau Official documents, China High-Speed Railway Projects Opened Already, [R], http://tieba.baidu.com/p/2803308902.

[14] Guangzhou daily, A New Round of High-Speed Railway Construction Boom: the most dense Yangtze River Delta and potential Pearl River Delta, [N], http://politics.people.com.cn/n/2013/1231/c70731-23987009 .html, 09:25, 12/31/2013.

[15] People's Daily, 2014 High Speed Railway business mileage over $16,000 \mathrm{~km}$ in the world, [N],

http://j.news.163.com/navi/99/2015013003/AH6664HA0001 4AED.html, and 03:13:00, 01-30-2015.

[16] Economic Daily, Forming a New Pattern of Modern Network of Express Cargo Logistics System, [W], http://www.ce.cn/cysc/jtys/tielu/201502/13/t20150213 4590 020.shtml, 09:11, 02/13/2015.

[17] Lianhe Zaobao, The Pan-Asia High-Speed Railway Shall Begin Construction from Kunming to Singapore Next Month, [N], Singapore, http://www.yzhcmw.com/a/3/05113A12014.html, 09-05-2014.

[18] Qi Zhongxi, Fan Xi, China's High-Speed Railway Total Mileage Reached $11,028 \mathrm{~km}, 50 \%$ of the world, [N], http://www.cet.com.cn/cjpd/jjsj/1126883.shtml,China Economic News Network, 14:49:04 03/06/2014.

[19] Rhapsody Information, Sino-USA High-speed Railway Plan across Eurasia! [W], http://www.08160.cn/hot/16543.html, 2015-05-28.

[20] Securities Times Online, Pan-Asia Railway is Expected to Break through from Thailand: Relevant Enterprises Welcome Development Opportunities, [w], www.news.gaotie.cn/guoji/ 2014-12-18/204979.html, 12/18/2014.

[21] Ju Fang, China's High-Speed Railway Network Covering the 17 Countries, Riding it from Beijing to London for just 48 Hours, Yangtze River Daily, [N], Http://news.qq.com/a/20100317/001006.htm, 09:42, $03 / 17 / 2010$

[22] Zhu Wanqing, Chinese Are Expected to Take the High-Speed Railway for 2 Days to the United States, Can the 13,000 km Going-out-Strategy Be Achieved? [W], http://xw.qianzhan.com/photo/detail/232/140509-b4577b0d. html, 08:51, 05/09/2014.

[23] Tao Duanfang, Beginning with 'take the train to the United States', [W],

Http://news.sina.com.cn/zl/zatan/blog/2014-05-13/13101409 /1463029193/57340dc90102epb2.shtml. 13:10, 05/13/2014.

[24] Cankaoxiaoxi, South America's First Transatlantic Railway Research launched a Total Length of $5,000 \mathrm{~km},[\mathrm{~N}]$, http://news.sina.com.cn/w/2015-05-21/111531859414.shtml, $11: 15,05 / 21 / 201505$.

[25] Asia Times: The Idea of Building a High-Speed Railway in China out of the Question, [W], http://www.doc88.com/p-2746687568548.html, 06/30/2015. 